\title{
Cümcüme Sultan Hikâyesi'nin Kökeni Üzerine Bir Giriş Denemesi ve Anlatının Mensur Bir Yeniden Yazım Örneği
}

\section{An Introductory Essay on the Origin of the Cümcüme Sultan and a Prosaic Rewritten Manuscript of the Story}

\author{
Meryem Babacan Bursal1 ${ }^{10}$
}

'Doktora öğrencisi, Boğaziçi Üniversitesi, Türk Dili ve Edebiyatı Bölümü, Istanbul, Türkiye

Sorumlu yazar/Corresponding author: Meryem Babacan Bursalı,

Boğaziçi Üniversitesi, Türk Dili ve Edebiyat Bölümü, 34342, Beşiktaş, İstanbul, Türkiye

E-mail: meryem.babacan@boun.edu.tr

Geliş tarihi/Date of receipt: 31.10 .2018

Kabul tarihi/Date of acceptance: 27.11.2018

\section{Atıf/Citation:}

Babacan-Bursalı, M. (2018). Cümcüme Sultan Hikâyesi'nin kökeni üzerine bir giriş denemesi ve anlatının mensur bir yeniden yazım örneği. TUDED 58(2), 247-280

https://doi.org/10.26650/TUDED2018-0008

\section{ÖZET}

Bu makale, Türk edebiyatı literatüründe Cümcüme, Dâstân-ı Cümcüme, Dâstân-ı Cimcime Sultan, Hikâyet-i Cimcime Sultan, Kıssa-ı Cümcüme gibi adlarla bilinen ve İsa Peygamber ile bir kuru kafa arasındaki konuşmayı konu edinen Cümcüme anlatısına odaklanmaktadır. Türk edebiyatında ilk örneğine Hüsam Kâtib'in yazdığı eserle rastladığımız bu anlatının, Doğu ve Batı Türkçesinde yazılmış mensur ve manzum birçok varyantı bulunmaktadır. İsa Peygamber karşılaştığı bir kuru kafanın öyküsü öğrenmek için Allaha dua eder ve duanın kabul edilmesi sonucu kuru kafa konuşmaya ve başından geçenleri anlatmaya başlar. Güçlü ve cömert bir hükümdarın öldükten sonraki hayatının ve cehennem tasvirlerinin yer aldığı bu anlatının Malay, Java ve Sunda dillerindeki örneklerinin yanı sıra Arapça, Farsça ve Çince yazıımış versiyonları da bulunmaktadır. Kökeni oldukça eskilere dayanan bu hikâyenin coğrafya, din ve kültür gibi etmenler sebebiyle bazı farklılıklar içerdiği de görülür. Bu çalışmada öncelikle anlatının kökeni hakkında bilgi verilmeye ve Türk kültüründeki yeri incelenmeye çalışılacaktır. Daha sonra ise tespit edilebilen on iki farklı anlatı üzerinden karşılaştırmalar yaparak anlatının hangi şekillerde karşımıza çıktığını analiz edilmeye çalışılacaktır. Ayrıca Yapı Kredi Sermet Çifter Kütüphanesi'nde bulunan bir örneğinin transkripsiyonu yapılacaktır.

Anahtar Kelimeler: Cümcüme Sultan, kuru kafa, İsa Peygamber, tercüme, yeniden yazım

\section{ABSTRACT}

This article focuses on the narrative of Cümcüme, an imagined dialogue between Jesus and a skull, known as Cümcüme, Dâstân-ı Cümcüme, Dâstân-ı Cimcime Sultan, Hikâyet-i Cimcime Sultan, or Kıssa-ı Cümcüme in Turkish literature. Hüsam Katib wrote the first Turkish version. Subsequent prosaic and poetic versions of the story were written and told in Eastern and Western Turkish languages throughout the centuries, including Malay, Java, and Sunda, Arabic, Persian, and Chinese. According to the narrative, Jesus prays to God to learn the story of a skull he comes across. The prayer is answered by means of the skull speaking and recounting its story. The skull describes the afterlife of a strong and generous ruler, who nonetheless ended in hell. The origin of the story dates back to very old times and differs according to geographical, religious and cultural contexts. In this article, I will first show the origin of the narrative in Turkish literature. Then I will compare twelve different versions and examine the formal and contextual changes. Finally, I will transcribe a manuscript from the Yapı Kredi Sermet Çifter Library.

Keywords: Cümcüme Sultan, skull, Jesus Christ, translation, rewriting 


\section{EXTENDED ABSTRACT}

The story named Cümcüme or Cimcime Sultan is a Turkish folk tale, variously classed as a saga, legend or parable. The story is a part of oral culture, handed down from its first Turkish version written by Hüsam Katib in AD 1368/H 770. The main theme is not exclusively Turkish. The theme exists in the literature of many cultures, especially Eastern and Asian, and throughout those traditions, the narrative transforms according to the geographical, religious and cultural contexts. Despite those differences, though, the principal narrative structure generally stays the same.

The first scripted version was discovered in the works of an 11th-century author, Abu Nuaym al-Isfahani. However, the story of Jesus and the skull, or Cümcüme Sultan has been a part of the oral culture in the Arabic literary tradition along the centuries.

Although the opening scene varies according to culture, it typically involves Jesus (or a comparable holy person) happening upon a skull, showing us the process of an adaptation depending on the culture.

Through the translation made by Hüsam Katib from a work arguably referred to Attar, the Cümcüme story enters in Turkish literature. In the intervening centuries, it has been rewritten many times in prose and poem. The versions, which are mostly found in the mecmuas and sagas, also give us an idea about the reading population. The manuscripts usually have grammatical mistakes and the prosody is flawed. Although the main theme is the largely the same in any given manuscript, the death of Cümcüme Sultan, the portrait of Angel of Death, the description of hell, and the information about the time and place can differ. In Arabic or Judeo-Arabic versions, the narrative has specific subjects like the layers of hell and the dead souls suffering there. These differences are the result of the cultural context. The narrative was based on a conversation between Jesus and the skull. In Turkish manuscripts the main elements are quite similar. At the beginning of the story, Jesus meets the skull and prays to God to learn its story. In response, the skull begins to talk and tell his story. Cümcüme Sultan was a wealthy and a generous ruler, but he didn't believe in the prophet of his time and was punished for his doubt with a horrible death.

In this part, the narrative describes the afterlife and hell in vivid detail. The sultan, who found himself in hell and suffered too much and prayed to God to born again as a man of faith. When his prayers come true, he came back to the world as a skull. After he meets Jesus, he believes in him and after a while dies as a faithful man.

The original story was named Dâstân-ı Cümcüme, Dâstân-ı Cimcime Sultan, Hikâyet-i Cimcime Sultan, and Kıssa-ı Cümcüme. In manuscripts found in libraries around the world, some claimed that Feridüddin Attar inspired Hüsam Katib and that this inspired the many Turkish versions of the story. But recent research shows that Attar's so-called Cümcümenamed work is dubious. Besides, the narrative has many older versions from different cultures. 
In this article, I've studied three particular issues. First is the introduction of Cümcüme Sultan's story in literature and its effects on manuscripts throughout the centuries. Second, I will relate the story's origin. Then, I will focus on the the narrative's formal and contextual differences in the Anatolian region of Turkey.

In the last part, I will compare twelve detected rewritten texts and examine the differences between them. I will add a transcription of the prose version of Cümcüme Sultan from the Yapı Kredi Sermet Çifter Library. The manuscript in this library is a literal version of Cümcüme Sultan translated by Hüsam Katib. This prose version was custommade to make the poetic narrative more apprehensible. In this manuscript, some suitable idioms and attitudes were translated into the Anatolian culture which proofs the text's accomplished adaptation. It could be defined as a tradaption example. 


\section{GíRiş}

Kaynaklarda Cümcüme veya Cimcime Sultan adıyla geçen anlatı; destan, hikâye, efsane, kıssa gibi çeşitli türlerle sınıflandırılan bir halk hikâyesidir. Türkçede ilk olarak 770/1368 yılında Hüsam Kâtib tarafından yazıldığı bilinen bu hikâye, sözlü kültürün bir ürünü olmasının yanı sıra yalnızca Türk kültürüne ait bir tema içermez. Özellikle Doğu ve Asya olmak üzere dünyanın çeşitli edebiyatlarında da izlerine rastlanılan bu anlatının varyantları, coğrafya, din ve kültür gibi etmenler sebebiyle bazı farklılıklar içerir; fakat bu farklılıklar anlatının ana yapısını bozmamaktadır.

Anlatı, Hazreti İsa ile bir kuru kafanın soru cevap şeklindeki konuşmaları üzerine kurulur. Türkçe yazılmış bütün varyantlarında anlatıdaki temel öğelerin benzerlik arzettiği görülür. Hazreti İsa'nın yolda yürürken bir kuru kafa görmesi ve bu kuru kafanın mahiyetini öğrenmek üzere Allah'a dua etmesiyle başlayan anlatı, Allah'ın bu duayı kabul etmesi ve kuru kafanın dile gelerek hikâyesini Hazreti İsa'ya anlatmasıyla devam eder. Zengin, güçlü ve halkına karşı çok lütufkâr bir hükümdar olan Cümcüme Sultan, yaşadığı zamanda gelen peygambere iman etmez ve bir gün hastalanarakölür. Anlatının bu kısmında öldükten sonra yaşananlar ve cehennem tasvirleri büyük yer tutar. Çok azap çeken ve cehenneme giden padişah, tekrar dünyaya gelip mümin olmak için Allah'a o kadar çok yalvarır ki sonunda duası kabul olur ve dünyaya bir kuru kafa olarak geri döner. Hazreti İsa ile karşılaştığında da ona iman eder ve bir müddet daha yaşadıktan sonra mümin olarak vefat eder.

Dâstân-ı Cümcüme, Dâstân-ı Cimcime Sultan, Hikâyet-i Cimcime Sultan, Kıssa-ı Cümcüme1 gibi isimlerle Türkiye ve dünya kütüphanelerinde çok sayıda versiyonu bulunan bu anlatının kökeni hakkında mevcut çalışmalarda yer alan bilgi, Hüsam Kâtib’in bu hikâyenin konusunu Feridüddin Attâr'dan alarak genişlettiği ve bu sayede Türk yazı dillerinde çeşitli şekillerinin kaleme alındığı yönündedir. Ancak yapılan çalışmalar Attâr'ın böyle bir eserinin olup olmadığı konusunda kuşku yaratmakta ve anlatının çeşitli kültürlerde çok daha eski zamanlarda yazılmış versiyonlarının bulunduğunu göstermektedir.

Bu çalışmada temel olarak üç nokta üzerinde durulmaya çalışılacaktır. Öncelikle Cümcüme Sultan'ın bir anlatı olarak edebiyata nasıl girdiğine odaklanılacak ve anlatının kökeni hakkında bilgi verilmeye çalışılacaktır. ${ }^{2}$ Daha sonra ise Türkçedeki Cümcüme Sultan yayınları üzerinden bu anlatının Anadolu sahasında başka hangi şekillerde karşımıza çıktığı incelenecektir. Son kısımda ise tespit edilen on iki metin ${ }^{3}$ üzerinden bir karşılaştırma

1 Arapça kökenli bir kelime olan Cümcüme'nin yurt dışındaki yayınlarda ve bazı kataloglarda "Gumguma, Cemceme, Ǧemǧeme, Jumjuma, Dzhumdzhuma" gibi çeşitli şekillerde yazıldığı görülmektedir.

2 Bu noktada, diğer araştırmalarla birlikte, en çok faydalandığım çalışma, Roberto Tottoli'nin kuru kafa motifinin ortaya çıkış ve gelişim sürecini incelediği “The Story of Jesus and the Skull in Arabic Literature: The Emergence and Growth of a Religious Tradition" başlıklı makalesi olacak.

3 Incelemeye konu edilen metinler şu şekildedir: Tansel, F.A. (1970). Cümcüme Sultân Ottoman Translations of the Fourteenth Century Kıpchak Turkic Story. Archivum Ottomanicum. C.Il. ss. 252 - 269; Cumbur, M. (1977). Cimcime Sultan Destanı. Türk Folkloru Araştırmaları Yıllığı 1976. Ankara: Kültür Bakanlığı MFAD Yayınları. 39 - 54; Önler, Z. (1991). Manzum Halk Hikâyelerinden Cümcüme Sultan. Fırat Üniversitesi Dergisi 
yapılacak ve anlatının yeniden yazımları arasındaki farklar tespit edilmeye çalışılacaktır. Makalenin son kısmında ise Yapı Kredi Sermet Çifter Kütüphanesi'nde bulunan mensur bir Cümcüme Sultan hikâyesinin transkripsiyonuna yer verilecektir.

\section{Cümcüme Sultan Hikâyesinin Kökeni}

Bir kuru kafanın Hazreti İsa ile olan konuşmasını içeren ve sözlü kültürün önemli bir ürünü olan Cümcüme Sultan anlatısı, Türkçe literatüre Hüsam Kâtib ile birlikte girmiş, anlatının daha sonra Türkçe birçok nazım ve nesir versiyonu yazılmış ve anlatı kısa fakat içerik itibariyle dikkat çekici bir metne dönüşmüştür. Hüsam Kâtib tarafından 1368 tarihinde yazılan Cümcüme-nâme'nin, Feridüddin Attâr'ın Cümcüme-nâme'sinden mülhem olduğu, Hüsam Kâtib'in esere Attâr'da bulunmayan bazı dinî motifleri dahil ettiği (Köprülü, 2004, s. 325; Şentürk ve Kartal, 2006, s. 116) konu üzerine çalışan araştırmacılar ve edebiyat tarihi yazarları tarafından tekrar edilen bir bilgi olarak karşımıza çıkmaktadır. Ancak bu hikâyenin yalnızca Farsça ve Türk dillerinde yazılmadığı, çok daha geniş bir coğrafya ve kültür havzasına ait olduğu anlaşılmaktadır.

Clara Brakel-Papenhuyzen anlatının erken dönem Grek-Mısır efsanelerinden inkişaf ettiğini ve bu anlatılarda kahraman olarak İsa yerine ünlü Mısırlı sufi Aziz Macarius'un yer aldığını aktarır $(2002, \text { s. } 1)^{4}$. Fabrizio Pennacchietti yayınladığı makalesinde 5 bu anlatıdan ilk bahseden kişinin 9. yüzyılda İshak bin Bişr olduğunu ve İshak bin Bişr'in de bu anlatıyı 7. yüzyılda yaşamış Ka'b el-Ahbar olarak bilinen Ebu İshak el-Himyerî'ye ${ }^{6}$ dayandırdığını, daha sonra ise anlatının Gazzali, Mevlânâ Celâleddin Rûmî tarafından bilindiğini ve Attâr tarafından manzum bir şekilde yazıldığını belirtir. (2005, s. 292). Cümcüme Sultan anlatısı

(Sosyal Bilimleri). 5 (2). ss. 351-367; Merhan, A. (2013). Dâsitân- । Cümcüme: Anadolu'da Türk Diliyle Yazılmış İlk Cümcüme Sultan Destanı. VI.Uluslararası Türk Dil Kurultayı Bildirileri. 20 - 25 Eylül 2008. Ankara: Türk Dil Kurumu Yayınları. ss. 3133-3146.Daşdemir, Ö. (2015). Düzyazı Şeklinde Yeniden Yazılan Anonim Bir Cümcüme Hikâyesi. Selçuk Üniversitesi Türkiyat Araştırmaları Dergisi. 37. ss. 387-414; Toker, M. ve Uygun, M. (2017). Çağatayca Cümcüme-name. Konya: Palet Yayınları; Dâstân-ı Cimcime Sultân. Milli Kütüphane Yazmalar Koleksiyonu 06 MilYz A 6823/6 numara.v. 22a-25a.; Dâsitân-ı Cimcime Sultân. Milli Kütüphane Yazmalar Koleksiyonu 06 Mil Yz A 3881/8 numara. v. 76a-80a. Ørum, O. G. (2017). 'Ușșit il-Gumguma or 'The Story of the Skull' with Parallel Versions, Translation and Linguistic Analysis of Three 19th-century Judaeo-Arabic Manuscripts from Egypt. Supplemented with Arabic Transliteration. Leiden-Boston:Brill.; Hāzāa Hikāyet-i Cimcime Sultan. Yapı Kredi Sermet Çifter Kütüphanesi 156/2 numara. v. 120b-129b. Padwick, C.E. (1930). The Nebi 'İsa and The Skull. The Muslim World. Volume 20, Issue 1. ss. 56-62. Hüsam Kâtib'in Cümcüme Sultan eseri için ise şu kaynaklardan yararlanıldı: Erol, M. (2006). Cimcime Sultan Destanı'nın Anadolu ve Tatar Eş Metinleri Üzerine Bir Mukayese. 1. Uluslararası Türk Dünyası Kültür Kurultayı. 9-15 Nisan 2006. İzmir; Türkiye Dışındaki Türk Edebiyatları Antolojisi Nesir- Nazım. (2001). "Tatar Edebiyatı”. c.18/2. (Latin harflerine ve Türkiye Türkçesine aktaran Fatma Özkan). Kültür Bakanlığı Yayınları: Ankara. ss. 93-99. Türkçe metinlerden Sermet Çifter Kütüphanesi'nde bulunan yazmanın yanı sıra Toker ve Uygun ile Daşdemir'in incelemelerine konu edindikleri metinler mensur diğerleri ise manzumdur.

4 Tottoli, Papa Gregory ve İmparator Trajan efsanesiyle kuru kafa ile İsa arasında benzerlik kuran bir çalışmanın da olduğu bilgisini verir (Tottoli, 2003, s.227).

5 Pennacchietti'nin İtalyanca makalesinden yapılan atıflar makaleye yazılan geniş İngilizce özete aittir.

6 Ka'b el-Ahbâr kişiliği ve İsrailiyyât'a dair rivayetleri sebebiyle hem yaşadığı dönemde sahabiler tarafından hem de bazı araştırmacılar tarafından eleştirilmiştir. El-Ahbâr hakkındaki bu eleştiriler için bkz: Kandemir, M.Y (2001). Türkiye Diyanet Vakfı İslam Ansiklopedisi. C. 24. ss.1-3., Ka'b el-Ahbâr maddesi. 
üzerine bir kitap çalışması bulunan Olav Gjertsen Ørum ise anlatının ilk yazılı versiyonunun 11. yüzyılda Ebu Nuaym el-İsfahânî tarafından meydana getirildiği bilgisini aktarır (Ørum, 2017, s. 15) ${ }^{8}$. Pennacchietti, anlatının ağılıklı bir şekilde İslâmileştirilmesine rağmen belirgin bir Hristiyanî havayı içerdiğini ve bu yüzden bu anlatının "tuhaf bir MüslümanHristiyan efsanesi" olarak tanımlandığına dikkat çeker. Ayrıca Pennacchietti efsaneyi Hristiyan ve Yahudilerin de benimsendiğini, onu kendi kültür ve dinî parametrelerine uydurduklarını vurgular (2005, s. 292). Ørum da anlatının Müslüman, Hristiyan ve Yahudi geleneklerine ait pek çok göndermesinin olduğunu belirtir $\left(2017\right.$, s. 16) ${ }^{9}$.

Cümcüme Sultan anlatısı bazı farklılıklarla birlikte birçok dilde yeniden yazılmıştır. Türkçe, Farsça ve Arapça dışında Malay ${ }^{10}$, Cava ${ }^{11}$, Sunda, Çince gibi dillerdeki tercümeleri (Pennacchietti, 2005, s. 292) anlatının ilgi çekici olduğunu göstermesinin yanı sıra sözlü kültürün yayııma alanını işaret etmesi bakımından da ayrıca dikkate değerdir.

Cümcüme'nin ortaya çıkışı ve gelişimi üzerine ayrıntılı bir inceleme yayınlayan Roberto Tottoli, Ebu Nuaym'ın Hilyetü'l-evliya ve tabakatü'l-asfiya adlı eserine kadar bu anlatının yazılı versiyonunun bulunmadığını; Ebu Nuaym'ın eserinde de anlatının iki versiyonunun bulunduğunu belirtir. Birbirinden tamamıla farklı olan ${ }^{12}$ ve biri diğerinden daha uzun olan bu iki versiyonun da Yahudilik'ten İslâm'a dönen Ka'b el-Ahbar'a isnad edildiğini belirten Tottoli, Ka'b el-Ahbar'ın Müslümanların ilk nesli arasında peygamberler ve Kitâb-ı Mukaddes'e ait gelenekleri yayma konusundaki rolüne (2003, s. 229) vurgu yaparak anlatının kökeni ile Yahudilik arasında da bir ilişki kurar.

Tottoli, Cümcüme üzerine yapılan yayınların seyrek olmasına rağmen el yazmalarında durumun farklı olduğunu ve kendisinin otuzdan fazla versiyon tespit ettiğini belirtir (2003, s. 241). Tottoli bu yazmalar üzerinden hem hikâyenin gelişimini hem de aynı ve farklı olan noktaları tespit etmeye çalışır. Buna göre anlatının temel yapısı şu şekildedir:

“Hazreti İsa bir gün bir kuru kafa görür ve Allah'ın verdiği izinle kuru kafa canlanıp yaşadığı zamanda cömert ancak puta tapan güçlü bir kral olduğunu anlatır. Uzun uzun krallığının gücünü, kölelerini, yaptırdığı şehirleri,

7 Arapça literatürdeki bu erken dönem İsa ve kuru kafa anlatıları için bkz: Khalidi, T. (2003). Müslüman Hazreti Isa. İstanbul: Kitap Yayınevi. ss.159-162;180-181;186-187.

8 Olav Gjertsen Ørum'un kitabına Türkiye'de ulaşmam mümkün olmadı. Kendisi çok büyük bir nezaketle kitabının PDF versiyonunu bana ulaştırdı ancak basımdan önceki son versiyonu kullandığım için olası herhangi bir sayfa karışıklığını giderme amacıyla bölüm başlıklarını dipnotta gösterdim: "On the Story गUș̦it il-Gumguma:The Muslim Version" bölümü.

9 "The Judaeo-Arabic Version" bölümü.

10 Malay takımadalarındaki anlatının versiyonları için bkz: Rosni bin Samah. (2014/2). Malay Takımadalarında Tasavvuf Edebiyatı. Tasavvauf IIImî ve Akademik Araştırma Dergisi. Uğur Boran, terc. Sayı 34. ss. 120-121.

11 Cava literatüründeki versiyonlar için bkz: Brakel-Papenhuyzen, C. (2002).

12 Ebu Nuaym'ın uzun anlatısı makalede de konu edinen versiyondur. Kısa olan anlatıda ise İsa Peygamber bir beyaz kafatası görür ve İsa'nın duasıyla kafatası yaşlı bir adama dönüşür. Elinde bir sebze torbası olan bu adam İsa Peygambere pazarın yolunu sorar, ona ömrünün son zamanlarında yaptıklarını anlatır ve anlatı bu şekilde sona erer (Tottoli, 2003, s. 231). 
oğullarını ve eşlerini tarif eder. Kuru kafa bir gün yıkanırken hastalanır birkaç gün sonra ölüm meleği (Angel of Death) onun canını almak için gelir. Cenaze ve defin merasiminin ardından ruhu bedenine geri döner ve melekler onun mezarını ziyaret ederler. Önce yaptıklarını yazmakla görevli iki melek gelir ve sonrasında da Münker ve Nekir onun imanını sorgulamak için gelirler. Kuru kafa, Tanrı tarafından cehenneme mahkum edilir. Günahkar insanlar cezalarını çekmek üzerine günahlarına göre sınıflandırılır ve cehennemin yedi tabakası anlatılır. Son olarak dünyada yaptığı iyiliklerin bir mükafatı olarak gökyüzünden gelen bir ses kuru kafaya cehennemden çıkması için izin verir. Kuru kafa Hazreti İsa'dan gerçek bir mümin olabilmesi için yaşama dönmeyi ister. Tanrının verdiği izinle de kuru kafa genç bir insan olarak hayata geri döner ve hayatının sonuna kadar bu şekilde yaşar" (2003, s. 243).

Tottoli'nin birçok yazmayı inceleyerek ulaştığı bu sonuç Türkçe Cümcüme Sultan anlatılarının da temel yapısını oluşturur. Özkan Daşdemir'in Türkçedeki diğer Cümcüme anlatılarını da karşılaştırarak hazırladığı incelemesinde de hemen hemen ana yapının aynı olduğu söylenebilir. ${ }^{13}$ Fakat Tottoli anlatının tüm versiyonlarında bulunan bu yapının dışında metinler arasında farklılıkların bulunduğuna dikkat çeker. Örneğin yazmaların bazılarında Hazreti İsa'nın kuru kafa ile karşılaştığı yere istinaden Kıyamet Vadisi; Suriye'de ismi verilmemiş bir vadi; Suriye'de ağaçlarla ve nehirlerle dolu bir vadi; ağaçlar, nehirler, kuşlar ve meyvelerle dolu bir vadi veya çimen ve bitkileriyle en zengin vadilerden biri olan Suriye'de 'Arwâ isminde bir vadi (Tottoli, 2003, s. 244) şeklinde farklı detaylar verilir. Kuru kafanın yaşadığı zaman dilimi hakkında da farklılıklar mevcuttur. Örneğin kuru kafa kimi nüshalarda Danyal Peygamber zamanında, kimi nüshalarda İlyas Peygamber zamanında, kimi nüshalarda Musa Peygamber zamanında ve kimi nüshalarda ise İlyas Peygamber zamanındaki Musa kavmi ile yaşadığını (Tottoli, 2003, s. 247) söyler. Yine anlatının yazıldığı kültüre göre ana kahramanın değiştiği, örneğin Şiî literatürde kahramanın İsa Peygamber değil Hazreti Ali olması (Tottoli, 2003, s. 233-235) ya da Müslüman kültürdeki örneklerde anlatının İslamileştirilmiş olması (Pennacchietti, 2005, s. 293) gibi bazı değişikliklerin olduğu görülür. Anlatının temel yapısında bir değişiklik yaratmayan ancak detaylarda farklılaşan bu yeniden yazımlar birer tradaptasyon örneği olarak da düşünülebilir. Hem anlatının genel yapısı bozulmadan yapılan tam bir çeviri hem de uygun bir şekilde yerel kültüre adapte edilen bu metinleri, çeviri ve adaptasyon arasındaki yakın ilişkiyi vurgulamak üzere, Michel Garneau'nun icad ettiği tradaptasyon (tradaptation) terimi (Bastin, 2011, s. 5) ile tanımlamak makul görünmektedir.

\section{Cümcüme Anlatısı Hakkındaki Türkçe Literatür}

F. Abdullah Tansel, bu esere ilk olarak Salemann ve Zhukovskıi'nin, daha sonra ise

13 Özkan'ın incelemesinde farkların çoğunlukla zamansal olduğu görülür. Örneğin kuru kafanın Zafer Önler ve Müjgan Cumbur'un metinlerine göre cehennemde kalma süresi bin yıl iken, Aziz Merhan'ın yayınladığı metinde bu süre yetmiş yıl, F.Abdullah Tansel'in hazırladığı metinde ise yüz yıldır (2015, s. 394). 
Türkçe literatürde Fuad Köprülü'nün dikkat çektiğini belirtir (1977, s. 252). Köprülü eserin dil tarihi açısından önemine dikkat çekerek eski Kıpçak sahasının mahsullerinden olduğuna ve zamanında oldukça meşhur ve önemli bir eser addedildiğine işaret eder (Köprülü, 2004, s. 325). Köprülü'nün vurguladığı bir diğer husus ise eserin içeriği itibariyle yayıldığı coğrafyadır:

“Eser baştan başa dünya, ahiret ve cehennem ahvali gibi dinî meseleler hakkındaki 'avami' İslam ideolojisinin bir ifadesi sayılabilir. Bu eser mevzuu itibariyle diğer bediî mahsullerden daha ziyade halk arasında yaşamış, sevilmiş, okunmuştur. Azerî ve Osmanlı sahalarında da bu mevzua büyük ehemmiyet verildiği malumdur." (2004, s. 326).

Köprülü'nün üzerinde durduğu popülarite, eserin tercüme edilmesini ve birçok defa yeniden yazılmasını sağlamış olmalıdır. Nitekim Köprülü'den bu yana anlatının çeşitli versiyonlarının tespit edildiği ve bunlar üzerine akademik incelemelerin yapıldığı görülmektedir. Eserin tespit edilebildiği kadarıyla Türkçe yazılmış altı yeniden yazımı mevcuttur. Bunlardan dördü manzum ikisi ise mensurdur. Özkan Daşdemir (2015), "Düzyazı Şeklinde Yeniden Yazılan Anonim Bir Cümcüme Hikâyesi" adıyla yayınlanan makalesinde bu hikâyenin mensur bir versiyonunu inceler. Daşdemir bu makalesinde daha önce yapılmış manzum Cümcüme Sultan incelemelerini de dikkate alarak F. Abdullah Tansel (1970), Müjgan Cumbur (1977), Zafer Önler (1991) ve Çiğdem Türker (2011) ile Aziz Merhan'ın (2013) yayınladıkları metinlerle kendi nüshası arasında karşılaştırmalar yapar ve diğer nüshalarda yer alan/almayan hususiyetleri dile getirir (2015, s. 391). Eserin Çağatay sahasında yazılmış başka bir mensur versiyonu da Çağatayca Cümcüme-nâme adıyla kitap olarak yayınlanmıştır. (Toker ve Uygun, 2017). Cümcüme Sultan üzerine bir başka çalışma da Mehmet Erol tarafından yapılmıştır. Erol, "Cimcime Sultan Destanının Anadolu ve Tatar Eş Metinleri Üzerine Bir Mukayese" başlıklı bildirisinde öncelikle Hüsam Kâtib ile Attâr'a isnad edilen Cümcüme-nâme adlı eser üzerinde bir karşılaştırma yapar. Daha sonra ise Müjgan Cumbur ve Aziz Merhan'ın yayınladıkları metinler ile Yapı Kredi Sermet Çifter Kütüphanesi'nde bulunan ve bu incelemenin de konusu olan metin üzerinden bazı karşılaştırmalar yapar. ${ }^{14}$ Ayrıca yapılan katalog taramalarında bu anlatının farklı versiyonlarına da rastlanılmıştır. ${ }^{15}$

14 Cümcüme Sultan üzerine yapılan bir başka çalışma da Arzu Çiftoğlu Çabuk tarafından yapılmıştır. Bu incelemenin de konusu olan Yapı Kredi Sermet Çifter Kütüphanesi'nde bulunan yazma, Çabuk'un çalışmasında tanıtılmış, özetlenmiş ve metinden bazı örneklere yer verilmiştir. Bkz: Çiftoğlu-Çabuk, A. (2018). Cümcüme Sultan hikâyesinin ilk mensur Türkçe çevirisi. İdil Dergisi, 7(48), 897-908.

15 Tespit edebildiği kadarıyla yine bu anlatının yer aldığı ancak hakkında henüz bir akademik çalışma yapılmamış yazmalardan bazıları şu şekildedir: Menkabetname ve Risale-i Cemceme Sultan. Arnavutluk Devlet Kütüphanesi. 443365 numara. Arnavutluk Devlet Kütüphanesi Online Katalogu. http://www. bksh.al/Katalogu/library/wwwopac/wwwroot/beginner/index_fr.html [Erişim tarihi: 23 Mayıs 2018]. Tüm çabalarıma rağmen bu yazmanın kendisine ulaşmam ve içeriğini görmem mümkün olmadı. Kütüphanenin sitesinde bu yazmaya ilişkin yönetici sınıfından Buşatlı Mustafa Paşa'nın mührünün yer aldığı belirtilmektedir. Mustafa Paşa, 1796-1860 yılları arasında yaşamış İşkodra'nın Bushat kasabasında İşkodra sancağı mutasarrıfığını elinde bulunduran ve Buşat (Bushati) köyüne nisbetle Buşatlı olarak tanınan aileye 
Eser hakkında yapılan araştırmalarda çoğunlukla dört unsurun öne çıktığı görülür. Bunlardan ilki esere adını veren "cümcüme" ya da "cimcime" kelimesinin anlamıdır. ${ }^{16}$

Tarama sözlüğü "cimcime" kelimesi için "tabanı paçavradan ve koncu çorap gibi ip ile örülerek yapılan bir çeşit ayakkabı" anlamını vermektedir. ${ }^{17}$ Erzincan Efsaneleri Üzerine Bir Araştırma (1993) adlı kitabında Ruhi Kara, "cimcime" kelimesinin kökenine ilişkin şu bilgileri verir:

"Cimcime kelime olarak, tabanı kalın bezden yapılmış, koncu ipten örülü bir çeşit ayakkabı manasına gelmektedir. Bektaşi dervişleri seyahate çıktıkları zaman Cimcime-Cemceme giyerlerdi. Hacı Bektaşî Velî́nin menkıbelerinden (Velayetname) Hacı Bektaş'ın Battal Gazi'yi ziyaret edip cemcemelerini bıraktığı kayıtlıdır. Bektaşilerin bir iş yaparken okudukları arasında bir de Cemceme Tercümanı vardır." (1993, s. 4)

Müjgan Cumbur sözcüğün derleme sözlüğündeki çeşitli ağızlardaki anlamlarını verdikten $^{18}$ sonra Mısır-Memlük kaynaklarında II. Bayezid'in kardeşi Cem Sultan'a "Cemceme Sultan" adının verildiğini vurgulayarak Cem Sultan'ın hayatı ve bilhassa ölümü düşünüldüğünde bu efsaneyle şehzade arasında uzaktan da olsa bir ilişki kurulabileceğine dikkat çeker (Cumbur, 1977, s. 54). İstanbul Arkeoloji Müzeleri Kütüphanesi'nde 1505 arşiv numaralı yazmanın 1b-8b varakları arasında bulunan metni $(2015$, s. 391) yayınlayan Ömer Daşdemir ise bu kelimenin anlamına ilişkin farklı bir açıklama yapar. Daşdemir, yayınladığı metinde sözcüğün etimolojisi ile ilgili bilgi verildiğini ve metne göre "Cimcime" isminin Arapça kökenli "cem" (toplama/yığma) sözcüğünden türediğini, Hazreti İsa çürümüş kemikleri bir yere "cem" ettiği (topladığı) için kemiklerden dirilen adamın isminin "Cimcime" olduğunu belirtir:

"Bunda rivâyet olunur ki, anın adı sonra Cimcime oldı. Zira İsa Aleyhisselam anın kemüklerin bir yere cem eyledi. Cimcime dimek cem manasıdır. Anın içün adı Cimcime oldı" (2015, s. 392).

Yapı Kredi Sermet Çifter Kütüphanesi'nde bulunan metnin başlığı da "Cimcime Sultan" okutacak şekilde harekelenmiştir. Bununla birlikte mevcut literatürün"19 "cümcüme"

mensuptur. Bu sebeple Buşatlı veya İşkodralı Mustafa Paşa diye anılır (Bilge, 2006, s. 344). Bu kişi bahsi geçen mührün de sahibi olmalıdır. Sultan Cimcime. Bodleian Kütüphanesi. MS. Ind. Inst. Turk 16/1. (Kut, 2003, s. 72). Katalogu hazırlayan Günay Kut bu eserin Çağatayca bir dinî hikâyeler mecmuası içinde bulunduğu bilgisini verir. Eser yazmanın 48b-60a varakları arasında yer alır. Dâstân-ı Cimcime Sultân. Milli Kütüphane Yazmalar Koleksiyonunda 06 Mil Yz A 6823/6 numarada yer alan bir cönk içindedir. Eser manzum olup yazmanın 22a-25a varakları arasında yer alır. Yine aynı kütüphanede 06 Mil Yz A 3881/8 katalog numarasında bir başka yazmanın içinde yer alan (76a-80a) ve Dâsitân-ı Cimcime Sultân başlığını taşıyan bir başka eser mevcuttur. Azerbaycan sahasında da Kelle-nâme adıyla geçen metinler bulunur. Bkz: Çınarcı, 2004, s. 51.

17 Bkz: http://www.tdk.org.tr/index.php?option=com_tarama\&view=tarama [Erişim tarihi: 23 Mayıs 2018].

18 Cumbur, Türkiye Halk Ağzından Derleme Sözlüğü'nde cimcime kelimesinin İstanbul-Üsküdar'da ufak-tefek; Afyon'da körpe-yavru; Trabzon'da cınbız; Kandıra'da cin mısırl; Denizli'de üstü açık terlik anlamlarına geldiğini aktarır (1977, s. 53).

19 Özellikle de İngilizce, Arapça ve Rusça literatürde bu kelimenin Cümcüme/Jumjuma/Gumguma/ şeklinde 
kelimesi üzerinden ilerlediği görülür. Bunun sebebi kelimenin çeşitli yazmalarda

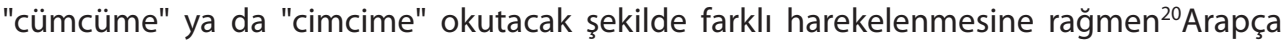
cümcüme kelimesinin anlamının sözlüklerde kafatası ve kuru kafa (Redhouse, 2011, s. 674; Steingass, 1998, s. 370) anlamlarına gelmesi, dolayısıyla da başlık ile içerik arasında doğrudan bir ilişkinin kurulabilmesi olmalıdır.

Anlatı üzerine yapılan ikinci bir tartışma da Hüsam Kâtib'in eserinin kaynağı ${ }^{21}$ üzerinedir. Araştırmacılar eserin Kıpçak sahasındaki ilk yazarı Hüsam Kâtib'in eserini, Feriddüddin Attâr'a isnad edilen Cümcüme-nâme adlı eserden genişleterek yazdığını düşünmektedir. Fuad Köprülü'nün “Bizim görüşümüze göre, Hüsam Kâtib’in eseri Feridüddin Attâr'ın Cümcüme-nâme'sinden iktibas edilmiştir" şeklinde verdiği bilgi eser üzerine yapılan neredeyse bütün çalışmalarda da dile getirilir. Köprülü'nün Zhukovskıi'nin çalışmasından²2 hareketle dile getirdiği bu görüşün aksine Attâr'ın böyle bir eserinin bulunmadığı düşünülmektedir. Zira Attâr'a ait olduğu düşünülen eserlerin birçoğunun XV. yüzyılda yaşayan Attâr-ı Tûnî tarafından yazıldığı ve bir kısmının da yine Attâr adlı veya mahlaslı diğer kişilerce kaleme alındığı belirtilmektedir. (Şahinoğlu,1991, s. 98). Ancak özellikle İngilizce literatürde, Cümcüme Sultan anlatısının önemli bir geliş̧im aşaması olarak Attâr'ın yazdığı metin sıklıkla vurgulanmaktadır. ${ }^{23}$

Eserle ilgili öne çıkan bir diğer husus bu eserin Kesik Baş Destanı ile olan ilişkisidir. Kesik Baş motifi, bir anlatı olarak hem Türk hem de dünya kültürlerinde çeşitli şekillerde işlenmiştir. Bu destanda Hazreti Muhammed Peygamber'in yanına bir kesik baş gelerek bir devin karısını kaçırdığını ve kendisinin de vücudunu yediğini söyleyerek ondan yardım ister. Bunun üzerine Hazreti Ali ile birlikte yola çıkan kesik baş, devin bulunduğu yere ulaşır. Hazreti Ali devi öldürüp kesik başın karısını ve diğer esir tuttuğu Müslümanları kurtarır. Hazreti Ali'nin ettiği dua ile kesik baş tekrar vücuduna kavuşur ${ }^{24}$. Kesik Baş ile Cümcüme Sultan anlatısı arasındaki temel benzerlik ana kahramanın bir kuru kafa olması ve hikâyenin sonunda bedenine kavuşarak yakışıklı ve güçlü bir kişiye dönüşmesidir. Ancak Müjgan Cumbur'un da belirttiği üzere masal yönü daha güçlü olan bu hikâyenin diğer destan ve efsane [Cümcüme Sultan] ile doğrudan hiçbir ilgisi kalmamıştır (1977, s.

yazıldığı ve "cimcime" kelimesinin kullanılmadığı dikkat çeker.

20 Ankara Milli Kütüphanede bulunan 06 Mil Yz A 6823/6 arşiv numaralı metnin Cümcüme olarak harekelendiği dikkat çeker. Buna mukabil 06 Mil Yz A 3881/8 arşiv numaralı metin "cimcime" okutacak şekilde harekelenmiştir.

21 Eser üzerine yapılan bir başka tartışma da eserin Fuzûlî́ye ait olduğu üzerinedir. Fuzûlî tarafından yazıldığı konusunda da birtakım iddialar bulunmakla birlikte Müjgan Cumbur yaptığı ayrıntılı taramalara rağmen şairin bu isimli bir eserine rastlamadığını, eserin Fuzûlî́ye olan aidiyetine Fuad Köprülü ve Abdülkadir Karahan'ın da şüpheyle yaklaştığını belirtir (Cumbur, 1977, s. 41).

22 Valentin Alekseevich Zhukovskıı̆nin çalışması için bakınız: "Legenda ob Isuuse i cherepe v persidskom stihotvornom skaze Attâra (Legend of Jesus and skull in the Persian poem by 'Attâr)", ZVORAO, v. 7, 1-4, 1893, pp. 63-72. Yaptığım taramalar sırasında bu metnin İngilizce veya Türkçe çevirisine ulaşamadığımdan bu çalışma üzerine ayrıca inceleme yapmam mümkün olmadı.

23 Attâr'a yapılan atıflardan bazıları için bkz: Pennacchietti (2005); Brakel-Papenhuyzen (2002).

24 Kesik Baş anlatısının geniş özeti, çeşitli varyasyonları ve farklı kültürlerdeki benzerleri için bkz: Ahmet Yaşar Ocak (2013). Türk Folklorunda Kesik Baş: Tarih-Folklor Illişkisinden Bir Kesit. İstanbul: Dergah Yayınları. 
52). Ancak Mustafa Argunşah'ın hem Tatar hem de Türkçe metinlerini yayınladığı Kesik Baş Destanı'ndaki bazı öğelerin ortaklığına dikkat çekmek gerekir. Örneğin,

"ism-i azam duasın okur idim

İsa birle men namaz kılur idim

Kala-ı Nuri menim şehrim idi ${ }^{25}$

Hızır Illyas munis hem-yarım idi

Yürür irdim men Hızır İlyas ile

Körer irdim başka ne yazmış ola" (Argunşah, 2002, s. 40)

beyitlerinde Hazreti Ali ile konuşan kuru kafanın İsa Peygamber'i gördüğü, İlyas Peygamber ile vakit geçirdiği anlaşılmaktadır. Cümcüme Sultan hikâyesinin de birçok varyantında Cümcüme'nin Illyas Peygamber zamanında yaşadığı ancak ona iman etmediği için cehennemle cezalandırıldığına değinilmektedir. ${ }^{26}$ Cümcüme Sultan'ın farklı kültürlerdeki yeniden yazımlarında, örneğin Şiî literatürde, hikâye kahramanının İsa Peygamber değil Hazreti Ali olduğu görülmektedir (Tottoli, 2003, s. 233 -235). Bu durumda, bu iki anlatı arasındaki benzerlikler değerlendirilirken bu anlatıların aynı kaynaktan gelen ve zaman içinde dinî ve kültürel şartların etkisiyle birbirinden farklılaşan yeniden yazımlar olup olmadığı tartışılabilir.

Cümcüme Sultan üzerinden bir diğer tartışmayı ise Zafer Önler yapmaktadır. Önler, Cümcüme Sultan hikâyesine çok benzeyen bir bölümün meşhur halk hikâyesi Kerem ile Aslı içinde yer aldığını söyler ve benzerliği şu şekilde kurar:

“Kerem ile arkadaşı Sofu bir yol kenarında bir kuru kafa görürler. Kerem, kafanın geçmişini merak eder. Sazına davranıp, manzum olarak öğrenmek istediklerini sorar. Kuru kafa dile gelip Kerem'in dörtlükler halindeki sorularına gene manzum olarak cevap verir. Diyaloglar halindeki bu söyleşmede özet olarak, eskiden bir şah olduğunu, çok zengin olduğunu, kapısında birçok kimse çalıştığını, ölümü hiç düşünmediğini, altmış yıl yaşadığını, yüz yıldan beri de burada yattığını anlatır. Görüldüğü gibi adların dışında değişen tek şey, Kerem hikâyesinde tek farklılık, kabir azabı, sorgu sualden söz edilmediğidir. Büyük ihtimalle Cümcüme Sultan hikâyesi halk arasında çok yayılmış ve bunun sonucunda Kerem ile Aslı hikâyesinin içine de böylece girmiştir"(1991, s. 373).

Anlatının, Türkiye sınırları içerisinde yalnızca metinlerde değil, hem mimarîhem de sözlü kültürde hâlâ canlılığını koruduğu görülmektedir. Nitekim Cümcüme Sultan anlatısının

25 Argunşah’ın yayınladığı Türkçe metinde de bu beyit şu şekildedir: "Kala-ı Zeyni hem benüm şârum durur/ Hızr dahi munis yarüm durur. Bu beytin farklı bir yazmadaki varyantı ise şu şekilde verilir: Kala-ı Zerrin idi şehrim benim / Şeyh Abdullah idi adım benim" (Argunşah, 2002, s. 61).

26 Burada dikkat çekmek gereken bir diğer mevzu da Argunşah'ın yayınladığı metnin aparattaki farklarıdır. Örneğin yukarıdaki beyitte İsa yerine, Argunşah'ın tespit ettiği bir diğer nüshada, Musa isminin geçiyor olmasıdır (2002, s. 40). 
Anadolu'da aynı zamanda mimarî anlamda etkili olduğu ve çeşitli türbe, ziyaret ve adak yerlerinin bu isimle anıldığı da görülür. Örneğin Erzurum ilinde Cumhuriyet Caddesi üzerinde bulunan bir yapının ismi Cimcime Hatun Kümbeti'dir. Sanat tarihçileri Hüseyin Yurttaş ve Muhammed Lütfi Kındığılı yapının kitabesi onarıldıktan sonra Erzurum'daki bu kümbetin asıl isminin "Çengal Hatun" türbesi olduğunu tespit etmiştir. Ancak oldukça eski olan bu yapının isminin halk tarafından uzun yıllar boyu "Cimcime Sultan" olarak anılması da oldukça önemlidir. (Yurttaş ve Kındığılı, 2011, s. 75-96).

Anadolu'nun çeşitli yerlerinde izine rastlanılan bu yapılarda dikkat çeken ise anlatı kahramanının isminin "Cimcime Sultan" şeklinde geçmesi ve Cimcime'nin cinsiyetinin kadın olmasıdır. Anadolu Evliyaları adlı kitabında Nezihe Araz "Şifalı kaplıcaların sahibi umumiyetle kadın evliyalardır. Hikâyeleri büyük değişiklik göstermez. Küçük farklarla hep birbirine benzer" (Akt., Tanyu, 1967, s. 121) diyerek bu cinsiyet değişimine bir açıklama getirir. Hikmet Tanyu Ankara ve Çevresinde Adak ve Adak Yerleri adlı kitapta Ankara'nın Haymana ${ }^{27}$ ilçesinde bulunan Cimcime Sultan adak yerinden bahsederken bu yere ismini veren Cimcime Sultan hakkında şu bilgilere yer verir:

"Adı ile Arap harflerinin cim'i arasında bir benzerlik bulanlar var. Üvey bir annenin kendi kızından çok güzel ve iyi kalpli olan üvey kızını kıskandığından, nihayet onu babasına yaptıkları telkin ve tesirler, kavga döğüşle evden uzaklaşmağa razı ediyorlar. Babası kızını hiçbir şey söylemeksizin, önceleri yalın bir tepe olan kaplıcaların bulunduğu sahaya getiriyor. O geceyi orada geçiriyorlar, babası kızını bırakıp kaçıyor. Yalnız kalan, güneş ışığı altında sıcak ve açlıktan bunalan kız hastalanıyor, vücudundan yaralar, çıbanlar çıkıyor; kızcağız tırnakları ile toprağı kazıyor, Tanrı yerden su kaynatıyor, onunla yıkanıyor, çıbanları geçiyor. Böylece buranın namını çobanlar, köylüler her tarafa yayıyorlar. Bu surette Haymana'nın meşhur kaplıcaları doğmuş oluyor. Bu kızın kerameti ve duasının kabul edilişi sebebiyle öldükten sonra büyük bir sevgi ve saygı görüyor" (1967, s. 121-122).

Yaşar Kalafat ise aynı ilçedeki adak yerine adını veren Cimcime Sultan ile ilgili benzer bir bilgiyi aktarır:

"Ankara ili, Haymana ilçesindedir. Buradaki şifalı kaplıca suyunu ilk bulan Cimcime Sultan olmuştur. Burayı çocuğu olmayan anne adayları ve kısmetleri açılması için genç kızlar ziyaret ederler. Ziyaretçiler yakın çevredeki ağaçlara adak çaputu asar, dilekleri kabul olunca tekrar gelip kurban keserler. Rivayete göre Cimcime Sultan'ın yüzünde ve vücudunda yaralar çıkar. Üvey annesi hastalık kendilerine de geçmemesi için onu evden uzaklaştırır. Kaplıcanın

27 Haymana'da aynı isimle bir de otel işletmesi bulunmaktadır. "Cimcime Sultan Termal Otel" adıyla hizmet veren bu kaplıca tesisi, bu hikâyenin çok farklı şekillerdeki tezahürlerinden birisi olarak karşımıza çıkmaktadır. Otelle ilgili bilgi için bkz: http://www.haymana.bel.tr/cimcime-sultan-termal-otel.html. 
bulunduğu yerde oynarken Cimcime Sultan bu su ile yıkanır ve tedavi olur. Cinsiyeti tartışma konusu olan Cimcime Sultan'ın genç bir kız olduğu, günün erken saatlerinde kaplıcaya gidenler sarı saçlı güzel bir kızı kaplıcada görünce anlaşılır" (2004, s. 42).

Cimcime Sultan adı ayrıca Erzincan'da bulunan Altıntepe adı verilen bir tepe ile de ilişkilendirilir. Efsaneye göre yıllar evvel bu tepenin olduğu yerde bir şato bulunuyor ve bu şatoyu da Cimcime Sultan adında bir kadın idare ediyordu (Albayrak, 1983, s. 144). Bu şatoda çok sayıda malı ve hizmetlisi bulunan Cimcime Sultan'ın zamanla daha da zenginleşmesi düşman kazanmasına sebep olur ve Cimcime Sultan düşmanlarından korunmak için şatonun etrafını toprakla doldurur. Bunun üzerine de Altıntepe isimli mevkinin oluştuğuna inanılır. Nurettin Albayrak bu tepenin üzerinde yıllar önce bir altın kazan bulunduğu ve Cimcime Sultan'ın servetinin burada olduğu sanıldığı için buraya Altıntepe dendiğini belirtir (1983, s. 144). Necdet Sakaoğlu, bu anlatının Mengücekoğulları́nın çok tanınmış bir hükümdarı olan Behram Şah'ın yaşamı üzerine kurgulanmış yaygın bir söylence (2005, s. 86) olduğunu belirtir:

“Bu masala göre, Cimcime Sultan’ın biri [Erzincan'ın] Cimin köyünde, diğeri Sadak'da iki sarayı; Köşünger köyünde de Sultan (İsmetî) Hatun'un, Köşk-i Nigâr diye anılan güzel bir köşkü varmış. Sadak Sarayı diye gösterilen harabeyi, Cimcime Sultan öyküsünü nakleden A. Kemalî Aksüt tanımlıyor ki bu kalıntı olasılıkla bir kervansaraya aitti. Masalda, Cimcime Sultan'ın cömertliği, konukseverliği anlatılırken: "Cimcime Sultan ${ }^{28}$ idim ben de kendi başıma / Günde on yük tuz giderdi aşıma lavaşıma" beytiyle başlayan bir manzume de okunarak bu Türk sultanının cömertliği, konukseverliği vurgulanırmış. Bu masalın kahramanı gerçekten Behram Şah ise onun zaman içinde Cimcime Sultan kimliğine büründüğünü öğreniyoruz." (2005, s. 86-87).

Cimcime Sultan'ın bir hikâye kahramanı olarak yer aldığı bir de çocuk kitabı mevcuttur. $\mathrm{Bu}$ versiyonda ise Cimcime, büyük ve şöhretli bir hükümdarın biricik kızıdır. Bir gün arkadaşı Derman ile ormanı gezmeye çıkar ancak başka bir ülkenin hükümdarı tarafından kendisiyle evlenmesi için kaçırılır ve orada tutsak edilir. Daha sonra babasının hastalandığı haberini alan Cimcime, şifalı bir ilaç yaparak babasına gönderir ve bu sayede babası hayata döner. Arkadaşı Derman ile tutsak bulundukları yerden kaçan ve babasına kavuşan Cimcime burada Derman ile evlenir (Aydınlı, 2003). Kitapta anlatının kökeni ile ilgili bir bilgi yer almaz ancak Cimcime'nin cinsiyetinin kız olması ve bir şekilde şifa veren, hastalıkları iyi eden bir pozisyonda olması bu anlatıyı da yukarıdaki versiyonlarla ilişkili kılmaktadır.

Bir kuru kafa ile İsa Peygamber arasında geçen bu diyalogun akla getirdiği bir başka örnek ise Shakespeare'in Hamlet eseridir. Nitekim Margaret Litvin Hamlet's Arab Journey adlı kitabında (2011, s. 209) Arapçada Hamlet'in yeniden yayınlanan versiyonları arasında Münacatu Cümcüme isimli bir kitabın bulunduğu bilgisini vermektedir.

28 Ali Kemalî Aksüt Cimcime Sultan'dan “Duki Bey” olarak bahsetmektedir (Kara, 1993, s. 4). 


\section{Cümcüme Sultan’ın Mensur Bir Yeniden Yazım Örneği}

Yapı Kredi Sermet Çifter Kütüphanesi'nde Hâzâ Hikâyet-i Cimcime Sultân başlığını taşıyan ve 156/2 numarada kayıtlı olan ${ }^{29}$ nüsha, 190x130;155x80 mm. ölçüsündedir. 19 satırdır. Kahverengi, meşin ve şemseli bir cilt içindedir. Eser, yazmanın 120b-129b yaprakları arasında yer alır. Başlık, cetvel ve metin içindeki bazı kısımlar kırmızı mürekkepledir. Aynı cildin içinde İbret-nümâ-yı Lâmî adlı bir eser daha bulunur. Mensur bir metin olan bu eserde yazı harekesizdir ancak başlık "Cimcime Sultan" okutacak şekilde harekelenmiştir. Eski Anadolu Türkçesi özellikleri göstermekle birlikte, tıpkı diğer Türkçe Cümcüme anlatılarında olduğu gibi, imla oldukça kusurludur. Müstensihin imla konusunda çok bilgili olmadığı anlaşılmaktadır. Müstensihin kimliğine veya istinsah tarihine dair herhangi bir kayıt yazmada yer almaz. Fuad Köprülü'nün Türk Edebiyatı Tarihi'nde bahsettiği nüsha da bu nüsha olmalıdır (2004, s. 325).

Bu mensur yeniden yazım, başlangıç bölümü itibariyle Türkçe nüshalardan farklılık arzeder. Zira eserin başında bir sebeb-i telif bölümü bulunmaktadır. Bu bölümde eserin Sahip Giray Han tarafından Türkçeye çevrilmesinin istendiği ve bunun üzerine de yazıldığı bilgisi yer alır. Sahip Giray Han (ö. 1551) bir gün hazine kitapları içinde bu eseri görür ve Hüsam Kâtib ${ }^{30}$ tarafından Moğol dilince yazılan metnin okuma ve dinleme açısından kolay olması için Türkçeye nesir olarak çevrilmesini ister. Bunun üzerine de eser Duacıya ${ }^{31}$ iletilir.

"ba'de bir gün ol han-ı 'âdil ü hakan-ı 'âkıl Sahib Giray Han bin Hacı Giray Han halleda'llahu'ale'l-'âlemîn tarih dokuz yüz elli beşte [1548-9] iken hazine kitapları içinde Cimcime Sultan hikayetin görmüş ki tarih yedi yüz yetmiş yedide [1375-6] Hüsam Kâtib Moğol dilince nazm etmiş amma bu acayip hikâyet ve garayip rivâyettir ki okuyup dinleyen Allâh Te'ala Hazreti pek kemal-i kudretin istidlal olur çün Hazreti Han bu kitabı görüp buyurmuş ki varun bu kitabı ezafü'l-'ibâd du'acımıza iledin Türkî dilince nesr eylesin okuyup dinlemeye âsân olsun deyip göndermiş" (v. 120b-121a).

F.Abdullah Tansel "Moğol dili" teriminin Çağatay sahasında kullanılan Türk lehçesine karşılık geldiğini; 15. ve 16. yüzyıl yazarlarınca Nevâıî́nin dilinin, Tatar dili, Türkçe veya

29 Bkz:Yücel Dağlı, vd., (Haz). (2001). Yapı Kredi Sermet Çifter Araştırma Kütüphanesi Yazmalar Kataloğu. İstanbul: Yapı Kredi Yayınları. s. 68. Nüshanın fiziki özellikleri bu katalogtan alınmıştır.

30 Bu makalede karşılaştırma yaparken Mehmet Erol'un bildirisini ve Fatma Özkan'ın Latin harflerine ve Türkiye Türkçesine aktardığı metinleri esas alacağım.

31 Duacı, Osmanlı teşkilatında ve tarikat hiyerarşisinde bir unvan olup dua eden kişi için kullanılan bir terimdir. İslâm Ansiklopedisi'nde bu terim şu şekilde izah edilmektedir: "Osmanlılar'da saray, merkez ve esnaf teşkilâtlarında dua ile ilgili görevleri yerine getirenler için kullanılan resmî bir unvan niteliği kazanmıştır. Bazı kayıtlarda duacı, duahan şeklinde de adlandırılan bu görevliler günlük mesainin başlaması sırasında, belirli merasim ve şenliklerde duruma ve zamana uygun dualar okurlardı. Ayrıca tekke ve zaviyelerde zikrin veya ayinin sonunda dua etme veya ettirme ile görevli kişiler hakkında da aynı tabirler kullanılmıştır. Duahanlık aynı zamanda tarikat hiyerarşisinde de bir üst makamı ifade etmektedir. Nitekim Mevlevîlik'te duacı (duâgû) dedelerinin diğer dedegân arasında önemli bir yeri olduğu gibi âyin esnasında da önemli vazifeleri vardı. Mevlevî gülbangı denilen dua bunlar tarafından yapılırdı." (İpşirli, 1994, s. 541). 
Moğol dili şeklinde adlandırıldığını belirtir (1970, s. 252). Köprülü de burada geçen Moğol dilinden maksadın eski Kıpçak lehçesi olduğunu belirtir (2004, s. 326). Burada dikkat edilmesi gereken, farklı diller arasında değil, Doğu Türkçesinden Batı Türkçesine bir dil içi çevirinin yapılıyor olmasıdır. Bir diğer dikkat çeken durum, çeviri sırasında eserin formunun da değiştirilmesinin istenmesidir. Osmanlı edebiyatında çoğunlukla akılda kalıcı ve ezberlenmesi kolay olduğundan; ayrıca sanat göstergesi sayıldığından şiir yaygın bir form olarak tercih edilmiştir. Ancak "basitleştirme ve anlaşılır olma gayesiyle" nazımdan nesre yapılan çevirilere de rastlanmaktadır. Örneğin süslü eserlerden hoşlanmayan, basit, hemen kavranabilir ve sözü uzatmayan öyküleri tercih eden III. Mehmed 14. yüzyılda kaleme alınmış bir aşk mesnevisi olan ışk-nâme'nin kolay anlaşılır bir şekilde nesre aktarılmasını ister. (Durmuş ve Gürbüz, 2017, s. 152).

\subsection{Cümcüme Anlatıları Arasındaki Bazı Farklar}

\subsubsection{Sebeb-i Telif}

Yukarıda da değinildiği üzere Sermet Çifter'de ${ }^{32}$ bulunan yazmanın diğer Türkçe nüshalardan ayrıştığı en önemli tarafı öncelikle sebeb-i telif kısmının bulunmasıdır. Hemen bütün nüshalar dünyanın ve dünyanın zenginliklerinin geçiciliğine vurgu yapar ancak eserin oluşum süreci ve mahiyetine ilişkin bilgi vermez. Sermet Çifter'de bulunan nüsha bu bağlamda diğerlerinden ayrılır. Sahib Giray Han'ın hazine kitapları içinde gördüğü hikâyenin Türkçeye çevrilmesi isteği üzerine bu eser yazılmıştır (v. 120b). Bir büyüğün ricası üzerine kaleme alınan ${ }^{33}$ ve bir anlamda sipariş edilen bu eser, Doğu Türkçesinden Batı Türkçesine "çevrilmiştir".

\subsubsection{Hazreti İsa ile Kuru Kafanın Karşılaşması}

Tottoli'nin incelemesinde Hazreti İsa ile kuru kafanın karşılaşma sahnesinin farklı yazmalarda farklı şekillerde olduğuna değinilmişti. İncelenen Türkçe yazma ve yayınlarda da karşılaşılan yer, ortam ve karşılaşma sahnesi gibi farklılıklar bulunmaktadır. SÇ nüshasında Hazreti İsa ile kuru kafanın karşılaşma sahnesi şu şekilde anlatılır:

“İsa Peygamber bir gün misafirlik kılup Şam mülkine geldi ittifak bir merg-zâr sahra göründü ol sahrada sular irüvan olmuş akar gelüp su kenarında oturdı kudretu'lllâh birle nazar ederken gözüne bir kabir göründü içinde bir ölü adem başı var emr-i Illâhi birle kararmış eti çürümüş magaraları [?] dökülmüşs Hazreti İsa anı görüp ibret aldı eyitdi kim vallahi bu kadar ömür sürdüm

32 Makalenin devamında henüz akademik bir neşri yapılmamış nüsha adları şu şekilde kısaltılarak verilcektir: Sermet Çifter Nüshası=SÇ; Milli Kütüphane'de 3881/8 numarada bulunan metin=A; Milli Kütüphane'de 6823/6 numarada bulunan metin=B; Fatma Özkan'ın çevirdiği metin=HK.

33 Osmanlı edebi üretiminde sebeb-i telifler önemli bir yer tutar. Çoğunlukla tekrar eden bu eser üretme biçimleri genellikle şu şekildedir: hükümdar yahut bir büyüğün isteği, hâtiften duyulan bir ses, iz bırakma gayesi, bir olay/durumdan etkilenme, bilgi/öğüt verme gayesi, iddia, ilham, Türkçe yazmanın önemini vurgulama gayesi, bir karşılık beklentisi ve görülen bir rüyanın etkisidir. Ayrıntılı bilgi için bkz: Kavruk, H. (2003). Türkçe Mesnevilerde Sebeb-i Telif. Malatya: Özserhat Yayınları. 
bunun gibi ölü baş görmedim diyü temaşa eyledi alnına nazar eyledi gördü kim iki satır hat yazılmış dimiş kim bu baş dünyada bin yıl ömr sürdü cümle ömründe aleme padişah oldı bundan sonra gine dirilüp başından niçe nesneler geçüp akıbet can murgı ten kafesinden uçısardur dimiş" (v.122a).

SÇ'deki bu anlatıya göre İsa Peygamber misafirliğe gittiği Şam'da suların aktığı, çimenlik bir arazide kuru kafayı bir kabir içinde görür. Kuru kafanın alnında iki satır halinde bin yıl yaşadığı, sultan olduğu ve dirilip başından birçok hadise geçtikten sonra tekrar öleceği yazılıdır. Tottoli nüshaların bazılarında İsa Peygamber'in kuru kafa ile karşılaştığı yerde yazılı bir metin de bulduğunu belirtir (2003, s. 232). Bu yazı ayrıntısı Hüsam Kâtib'de de vardır. Hüsam Kâtib'de İsa Peygamber Şam'da suların aktığı, kuşların cıvıldadığı, yeşil bir vadide abdest almak için bir su kenarına oturur ve orada üzerinde bir insan başı olan bir taş görür:

"Baktı yazılmış altında iki mektup:

Sen ey baş böyle gezip böyle yat

Yine senden böyle işler geçecek

Sonra canının kuşu senden uçacak" (HK, 2001, s.95)

İncelenen diğer nüshalarda ise bu ayrıntının yer almadığı görülür. Örneğin Daşdemir'in yayınladığı nüshada İsa Peygamber yolda giderken bir çürümüş kemik görür ve eline alarak kemiğin kendisiyle konuşmasını ister (2015, s. 406). Burada kuru kafanın yerini kemik almıştır. Çağatayca nüshada ise İsa Peygamber'in kırda yürürken bir kuru kafa ile karşılaştığı (2017, s. 71); Önler, Merhan ve A nüshasında yolda yürürken (Önler, 1991, s. 375-376; Merhan, 2013, s. 3138; A, v. 76a) bir kuru kafa gördüğü (B, v.22a); Tansel'in incelediği nüshada İsa Peygamber'in Tur yolunda yürürken kuru kafayı gördüğü (1970, s. 258) yazılıdır. Cumbur ve B'de karşılaşma anından bahsedilmez; İsa ile kuru kafanın doğrudan konuşmaya başladığı görülür (Cumbur, 1977, s. 43; B, v. 22a). Ørum'un metninde ise karşılaşılan yer Suriye'dir (2017, s. 23). Padwick'in tercümesinde ise İsa ile kuru kafa Suriye'de ağaçlar ve akarsularla dolu, kuşların Allah'ı hamdettikleri bir vadide karşılaşırlar (1930, s. 56).

Kuru kafa ve İsa'nın karşılaşma alanı olarak genellikle Suriye'nin verilmesi dikkat çeken bir ayrıntıdır; anlatının kökeninin buraya dayanıyor olabileceği intimalini akla getirir. Nitekim Tottoli'nin incelediği yazmalarda da çoğunlukla spesifik olarak belirtilen yer ismi Suriye'dir (2003, s. 244). Ayrıca Padwick'in tercümesinde kuru kafa kendisini tanıtırken daha önce Suriye'nin krallarından biri olduğunu belirtir (1930, s. 57).

Yukarıdaki örneklerde görüldüğü üzere SÇ nüshası ile Hüsam Kâtib'in metninde İsa Peygamber'in kuru kafa ile karşılaştığı yer, Şam'da yeşillikler içinde bir vadidir. SÇ nüshasının Hüsam Kâtib'in metninin bir yeniden yazımı olduğu bilinmektedir ve nitekim bu yeniden yazımda bazı ufak farklılıklar göze çarpmaktadır. Örneğin SÇ nüshasındaki vadide kuş cıvıltılarından ve İsa Peygamber'in abdest almak için durduğundan bahsedilmez. Yine 
ayrıca kuru kafa ile karşılaşılan yerde her iki nüshada da "iki satır yazı"dan bahsedilir. Hüsam Kâtib'in metninde bu yazı kuru kafanın altında (2001, s. 95), SÇ nüshasında ise alnındadır (v.122a). Kuru kafanın başına gelmiş ve geleceklerin Anadolu sahasındaki metinde alın bölgesine yazılı olmasının bir manası olmalıdır zira "alın yazısı" Türkçede kişinin kaderi, yazgısı anlamına gelmektedir. Bu anlamda sadece Duacı rütbesinde bir kişi olduğundan başka hakkında bir şey bilmediğiniz SÇ müellifinin eseri çevirirken aynı zamanda yaşadığı bölgeye adapte etme eğilimi taşıdığı da düşünülebilir.

\subsubsection{Cümcüme Sultan'ın Ölüm Sebebi}

Cümcüme Sultan, İsa Peygamber ile karşılaştıktan ve İsa'nın duası üzerine konuşmaya başladıktan sonra dünyada çok ulu bir padişah olduğunu, çok zengin, güçlü ve cömert bir insan olduğunu anlatmaya başlar. Anlatının bu kısmında birçok hizmetçisi, malı, mülkü olduğundan bahseden Cümcüme'nin ${ }^{34}$ ölüm nedeni de nüshalar arasında farklılık gösterir. SÇ nüshası ile Hüsam Kâtib'in metni dışında diğer nüshalarda bir gün hamama gittiğinden ve orada hastalanarak öldüğünden bahsedilir. (Daşdemir, 2015, s. 407; Toker ve Uygun, 2017, s. 72; Tansel, 1970, s. 259; Cumbur, 1977, s. 45; Önler, 1991, s. 378; Merhan, 2013, s. 3141; A, v. 77b; B, v. 23a; Ørum, 2017, s. 33; Padwick,1930, s. 57).

SÇ nüshasında ise Cümcüme'nin ölüm nedeni şu şekilde verilir:

“Bir gün safa-yı kalble meclis kurup otururdum îş u işret-i safaya meşgul idim ol gül yüzlü sünbül zülüflü hatunlarım yanımda sağ u sol oturmuşlar idi ol hub yüzlü mergub sözlü cariyelerim kimi tacım tutar idi vü kimi kaftanım tutarlar idi bu halde iken gözüme bir özden mahbub gözüme düş oldı gönlüm ana düşdi ol nigarı yanıma alıp bir halvet-haneye vardum zevk itmege meşgul oldum ittifak mahremlerden biri gelüp eyitdi kapıya bir fakir geldi sizden ihsan u en'am diler didi ol dem ben hod dil-dâre meşgul idim gözime alem görinmez idi eyitdim ki iy ahmak şimdi ihsan zamanı mıdır didüm meger ol kul benim sözümü ol fakire dimişdi anun gönlü yıkılıp gitmiş sonra halvet-haneden kalkıp ol fakiri çok arandım bulamadım andan gusl idüp pâk olmak muradum idi soyunup başıma bir iki tas su dökince bir illet zahir oldı na-çâr başuma çokdı gözim karardı aklum gitdi yere düştüm halet-i nez'a vardım"(v. 124a-124b).

Anlatıya göre Cümcüme Sultan sevgilisiyle vakit geçirirken kendisinden yardım talep eden bir fakiri geri çevirir ve üstelik kendisini rahatsız eden kul Cümcüme'nin "ey ahmak şimdi ihsan zamanı mıdur" sözünü bu fakire aktarır. Kalbi kırılan fakir de oradan ayrılır ve Cümcüme daha sonra onu arayıp hatasını telafi etmeye çalışsa da bu fakir kişiyi bulamaz. Hadisenin akabinde de hastalanarak ölür. Hüsam Kâtib'de de anlatı SÇ ile uyumludur:

34 Cümcüme Sultan'ın dünyadaki zenginliği ve mallarının sayısı ile ilgili nüshalarda değişik rakamlar mevcuttur. Ömer Daşdemir çalışmasında bu farklılıklara değinmektedir. Bkz: Daşdemir, 2015, s. 293-396. 
“Eğlencedeyken dinle sözümi

Çarptı bir sevgilime ansızın gözüm

Aldım onu yanıma zevk etmeye

Beraber yatıp kucaklaşıp eğlenmeye

Ansızın bir görevli gelip söyler

"Bir fakir geldi yardım diliyor."

Ben o an meşguldüm kendimle

Ki görünmez idi alem gözüme

Dedim "Ey ahmak yardım vakti midir?

Ne sana ne başkasına zaman ayrılacak vakittir."

Sonra gittim hamama ben

Kirlilikten kurtulup yıkanmaya" (HK, 2001, s. 97-98).

Diğer nüshalarda geçmeyen "fakir kişinin kalbinin kırılması" hadisesi ve Cümcüme'nin ölüm şekillerine Tottoli'nin incelemesinde de rastlanılmaz. Tottoli yalnızca nüshalarda Cümcüme'nin ölümüyle ilgili büyük farklar olduğunu belirtir (2003, s. 247). Attâr'a atfedilen metinde de Cümcüme'nin ölüm nedeninin belirsiz olduğuna, bir av dönüşü aniden rahatsızlanıp öldüğüne dikkat çeken Mehmet Erol (2006, s. 833), burada geçen "Bardım andın sonra hammamga ben/ Kim ağrııızlıkdın özümni yuvam" şeklindeki beyti vurgulayarak Hüsam Kâtib'in Cümcüme Sultan'a halvet sonrasında putperest olmasına rağmen gusül abdesti aldırdığına dikkat çeker (2006, s. 834). SÇ müellifi de bu kısmı "gusl idüp pak olmak muradum idi" şeklinde ifade etmektedir. Eldeki verilerden hareketle bu durumda anlatının Türkçe versiyonunun genişletilmiş ve adapte edilmeye çalışılmış olduğu göze çarpmaktadır.

\subsubsection{Cümcüme Sultan'ın Hastalığı ve Ölü Kalma Süresi}

Nüshalarda farklılık gösteren bir diğer durum da Cümcüme'nin İsa Peygamber ile karşılaşmadan önce ne kadar ölü vaziyette kaldığıdır. Daha önce de değinildiği üzere özellikle sayı bildiren durumlarda bu farklııklara sıklıkla rastlanmaktadır. Cümcüme'nin İsa Peygamber'in "sen ne kadar zamandır ölü haldesin?" şeklindeki sorusuna verdiği cevaplarda kesinlik görülmekle birlikte bu cevapların oldukça çeşitli olduğu da dikkat çekmektedir. Aşağıdaki örneklerde bu farklılık görülmektedir:

Cümcüme Sultan hamamda hastalandıktan sonra 5 gün hasta yatar, sonrasında ölür ve 100 yıl ölü halde kalır (Daşdemir, 2015, s. 407).

Cümcüme Sultan hamamda hastalanır, kaç gün hasta yattığı belirtilmez, 10 bin yıl ölü halde kalır (Önler, 1991, s. 378).

Cümcüme Sultan hamamda hastalandıktan sonra 2 gün hasta yatar, sonrasında ölür ve 10 bin yıl ölü halde kalır (Cumbur, 1977, s. 45-46; Tansel, 1970, s. 259).

Cümcüme Sultan hamamda hastalandıktan sonra 5 gün hasta yatar, 
sonrasında ölür ve 3 bin yıl ölü halde kalır (Toker ve Uygun, 2017, s. 72).

Cümcüme Sultan hamamda hastalandıktan sonra 5 gün hasta yatar, sonrasında ölür ve 7 yüz yıl ölü halde kalır (Merhan, 2013, s. 3141).

Cümcüme Sultan hamamda hastalandıktan sonra 5 gün 5 saat hasta yatar, sonrasında ölür ve 470 yıl ölü halde kalır (Ørum, 2017, s. 33-35).

Cümcüme Sultan hamamda hastalandıktan sonra 6 gün hasta yatar, sonrasında ölür ve 47 yıl cehennemde azap çeker (Padwick, 1930, s. 58,62).

Cümcüme Sultan hamamda hastalandıktan sonra 2 gün hasta yatar, sonrasında ölür ve bin yıl ölü halde kalır (A, v.77b-78a).

Cümcüme Sultan hamamda hastalandıktan sonra 5 gün hasta yatar, sonrasında ölür ve 12 bin yıl ölü halde kalır (B, v. 23a).

SÇ nüshasında ise hastalandıktan sonra yedi gün hasta yattığını (v.125a) ve sonra öldüğünü söyleyen Cümcüme Sultan, cehennemde 4 bin yıl azap çektiğini anlatır (v. 128b). Hüsam Katib'te ise kaç gün hasta yattığına dair bir bilgi yoktur ancak cehennemde kaldığı süre SÇ ile aynıdır (Erol, 2006, s. 836).

Cümcüme'nin cehennemde kalma sebebi ise kendi zamanında gelen Illyas Peygamber'e itaat etmemesidir: "ol vakt Illyâs Nebî gelmiş idi ne ona uyduk ve ne Tengriye inandık (...) kendi kanımıza kendimiz girdik ol sebepten dört bin yıl azap çekdim dedi" (SÇ, v.128b). Hüsam Kâtib'in metni de SÇ nüshasıyla bu noktada ittifak eder (Erol, 2006, s. 837). Diğer iki mensur metinde de Illyas Peygamber zamanında yaşadığını söyleyen Cümcüme (Daşdemir, 2015, s. 411; Toker ve Uygun, 2017, s. 85) Çağatayca metinde şeytana taptığını, ona itaat ettiğini ve o ne derse yaptığını anlatır (Toker ve Uygun, 2017, s. 85).

Nüshaların bazılarında ise cehennemde yanmasının sebebi puta tapması olarak belirtilir ve hangi Peygamber zamanında yaşadığı söylenmez (Tansel, 1970, s. 261; Cumbur, 1977, s. 49; Önler, 1991, s. 381; Merhan, 2013, s. 3145; A, v.79b; B, v. 25a). Mısır'daki Yahudi-Arap anlatısı ise çok lütufkâr ve iyi bir insan olan Cümcüme'nin ömrünün son zamanlarında şeytana uyduğunu ve Allah'a itaatsizlik ederek puta taptığını söyler (Ørum, 2017, s. 31). Diğer versiyonlara göre daha kısa olan Padwick'te ise niçin cehenneme gittiğinden bahsedilmez.

\subsection{5. Öldükten Sonraki Hayat: Ölüm Anı ve Azrail}

Cümcüme Sultan'ın öldüğü zaman ile tekrar bir kuru kafa olarak dünyaya döndüğü zamana kadar yaşadıkları da nüshalara göre farklılıklar gösterir. Incelenen nüshalardaki en geniş anlatım biçimine SÇ'de yer verilmiştir. Ölüm anında ölüm meleğini gören Cümcüme Sultan Azrail'i şu şekilde tarif eder:

"nâ-gâh gözüme bu cihan bir ulu sahra göründü ol dem ferşimde bir ulu kimesne çıka geldi altı yüzü var gözleri od gibi yanar ve iki kanadı şark ile garb arasında tutmuş anun adına Azrấîl derler imiş bir elinde bir harbe var 
bir elinde bir kadeh var kim andan içen her giz ferah görmez andan korkup sual ettim senin yüzün neden altıdır biri yukarı ve biri aşağı ve biri ardına ve biri altına ve biri sağına ve biri solunadır dedim ol eyitti kaçan üstün yüzümü açsam gökte melekler can verir ve sağ yüzümü açsam evliyalar enbiyalar can verir ve anların güzidesi Habïbu'llâh Muhammed Mustafa ol nübüvvet madeninün gevheridir ve keramet kânınun cevheridir (...) ve sol yüzümü açsam kafirler can verir ve aşağı yüzümü açsam cümle yer halkı can verir dedi" (v.125a-125b)

SÇ nüshasındaki bu Azrail tarifine Hüsam Kâtib'de (HK, 2001, s. 98), Çağatayca Cümcümenâme'de (Toker ve Uygun, 2017, s. 72) ve Ørum'un Mısır'da bulunan, 19. yüzyılda yazılmış üç Yahudi-Arap elyazmasını incelediği çalışmasında da (2017, s. 37) rastlanır. Ancak Ørum'un çalıştığı el yazmalarında durum biraz daha farklıdır. Yukarıdaki anlatılarla benzerlik arzetse de bu yazmalarda Azrail tarifi diğerlerinden ufak da olsa önemli noktalarda ayrılır:

“Ölüm meleğinin iki ayağı yerde ve başı göktedir. Tüm vücudu gözlerle kaplıdır. Biri merhamet diğer intikam olmak üzere iki kanadı vardır. Bir kırmızı göğsü bir de beyaz göğsü vardır. Saçının rengi tamamen beyazdır. Biri sağda biri solda, biri arkasında biri önünde, biri başının üstünde ve biri çenesinin altında olmak üzere altı yüzü vardır. Bu yüzlerden sağdaki İsrail'in ruhlarını, soldaki cennet-i âlâdakileri, sakalının altındaki dünya halkını, ön yüzü cehennem halkını, arkasındaki yüzü ise kafirleri görür" (2017, s. 37-39).

Burada Tottoli'nin vurguladığı ve daha önce de değinildiği üzere eserin oluştuğu zemin anlatıya da etki etmiş ve dolayısıyla da Yahudilik izleri metne bir şekilde dahil olmuştur.

Padwick'in tercüme ettiği metinde ise Azrail'in yedi yüzü vardır ve bu yüzlerden birisi ki Azrail'in en iyi yüzü budur, Allah'ın sevdiği ve sonraki günlerde bir peygamber olarak göndereceği Muhammed ümmetinin ruhlarını kaplamıştır (1930, s. 58).

Padwick'in tercüme ettiği metinde İslâmî unsurların diğer nüshalara göre daha fazla yer aldığı görülür. Nitekim bu metinde kuru kafa, ölüm anı geldiğinde meleklere kendisini bırakmaları karşılığında tüm zenginliğini vereceğini söyler. Melekler ise kuru kafaya Nahl Suresi 61. ayetle karşılık verirler: "Ecelleri geldiğinde ne bir saat geciktirebilirler ne de onu ileri alabilirler"(1930, s. 59). Bu metinde ayrıca Muhammed Peygamber'in adının geçtiği kısımlarda "selam onun üzerine olsun" manasına gelen ve İslâmî literatürde peygamberin adının geçtiği yerde ona "salavat getirmek için" kullanılan ibarenin geçtiği görülür (Padwick, 1930, s. 60-61). Bu da söz konusu metnin Müslüman bir kimseye ait olduğunu düşündürmektedir.

Can alıcı melekle ilgili diğer nüshalarda farklı anlatımlar bulunur. Ölüm meleği bu nüshalarda Melekü'l-mevt (Daşdemir, 2015, s. 408) ve Can Alıcı (Tansel, 1970, s. 259; Cumbur, 1977, s. 46; Merhan, 2013, s. 3141; A, v. 78a; B, v. 23b) olarak isimlendirilir. Tüm bu nüshalar arasında ölüm anını en dehşetli ve ayrıntılı bir şekilde anlatanlar ise Arkeoloji Müzesi'nde 
bulunan metin (Daşdemir, 2015, s. 408), Ørum'un yayınladığı metin (2017, s. 41-43) ve Çağatayca yazılmış metindir (Toker ve Uygun, 2017, s. 82-83). Örneğin Çağatayca yazılmış metinde Cümcüme Sultan'ın dilinden yaşananlar şöyle anlatılır:

“Ey Ruhullah! Ölüm meleğinin yetmiş melekle geldiğini gördüm. Başım üstünde durdular. (Ölüm meleği) bir meleğe bunun dilini tutunuz, konuşmasın diye emretti. Eğer benim dilimi tutmasalardı feryad ederdim. Doğu ve batı halklarının yürekleri parçalanırdı. Başka bir meleğe 'Bunun kol (ve) ayaklarını tutun, kımıldamasın' diğer otuz meleğe (ise) 'Bütün organlarına basın' diye buyurdu. Ayrıca otuz ateşli gürz ile vurdular. Ey Ruhullah bir meleğe daha 'Bunun boğazını tutun' diye buyurdu. Boğazımı tuttular, canımı alacak oldular. 'Ey meleklerim, bana mühlet verin. Canımı ve bütün varlığımı size vereyim' dedim. Bir şamar vurdular. Bütün organlarım birbirinden ayrıldı. 'Ey âsî, bizler Allahu Teala'nın emrine göre hareket ederiz. Sen onun emrine göre hareket etmedin. Bu azaba mahkum oldun dediler" (Toker ve Uygun, 2017, s. 82-83).

\subsubsection{Cehennem Tasvirleri ve Azap}

Incelenen Cümcüme Sultan anlatılarında diğer noktalarda olduğu gibi cehennem tasvirleri ve Cümcüménin burada yaşadıklarıyla ilgili çeşitlilik söz konusudur. Ancak hem cehennem tasvirlerini hem de cehennemdeki kişilerin ahvalini en ayrıntılı şekilde veren versiyonlar mensur nüshalardır. Örneğin SÇ nüshasında cehennem, cehennemin kademeleri ve orada bulunan insanlar, günahkarların çektiği azaplar şu şekilde anlatılır:

"Tamu yedi kattır birbirinden ıssısı ziyadedir aşağı tamunun adı Hâviyedir anun azabı cümlesinden eşeddir ana münafıklar girer ikinci tamunun adı Sakardır ana Yehudiler girer (...) bu yedi tamunun her birinde dürlü dürlü azaplar vardır hergiz birbirine benzemez anda bir bölük kavim gördüm kim ağızlarından irinler akar şöyle murdar kokar kim cehennem anlardan incinir meğer anlar haram yiyenler imiş yine bir kavm dahi gördüm ayakları yukarı başları aşağı azap çekerler meğer anlar benlik davasın kılıp ayrı baş çekenler imiş (...) gözüme üç bölük adam göründü ben bunlardan sordum kim siz ne kişilersiz dedim bunlar eyitdiler biz dünyada mal u mülk ıssı ulu sultanlar idik şimdi gör halimizi ne oldu dediler eğer bu ahvali bize olacağın bileydik dünyada aç zelil geçinirdik keşke cihanda padişahlar olmaktan fakir-hâl olaydık âh edip ağlaşırlar çünkü cihan sultanlarının sonu budur vay ana kim cihanda padişah olup gafil tebasın dahi ol tabut içinde gördüm ki akrepler yılanlar ve çayanlar anları sokarlar etleri ol yılanların dişlerinde kalır hemân etleri dökündügi gibi geri bir saatten sonra yeniden etler bitip ol akrepler yine yerler idi beni tabut içine koydukları gibi ol yılanlar ve ol akrepler ve ol çiyanlar ol azabı gelip bana dahi itmeye başladılar" (v.126b-128a). 
SÇ nüshasında cehennemin tabakaları, bu tabakada bulunan ve cehennemde farklı şekillerde azap gören insanlar ayrıntılı şekilde anlatılır. Ancak Türkçe yazılmış diğer nüshalarda bu ayrıntıların yer almadığına dikkat çekilmelidir. Yalnızca Arkeoloji Müzeleri Kütüphanesi'nde bulunan yazmada diğerlerinden farklı olarak Cehennemin katları zikredilir ancak detaylandırılmaz (Daşdemir, 2015, s. 409-410). Nüshalarda cehennem tabakaları ve bu tabakalarda kimlerin yer alacağı tutarlılık göstermese de SÇ'deki bu cehennem ayrıntılarına Çağatayca yazılmış Cümcüme Sultan ve Padwick'in tercüme ettiği metninde rastlanır:

"Ey Ruhullah, cehennem yedi kattır. Her birinin azabının sonu yoktur. Hiçbir dille anlatılmaz. İlk tabakaya Haviye derler. Münafıkların yeridir. İkinci tabakaya Sair derler. Yahudilerin yeridir. Üçüncü tabakaya Cahim derler. Hristiyanların yeridir. Dördüncü tabakaya Sakar derler. Kendi nefisleri için kafir olan kimselerin yeridir. Beşinci tabakaya Hutame derler. Günahkarların yeridir. Altıncı tabakaya Siccin derler. Yedinci tabakaya Cehennem derler. İnandıklarını yapmayan Hazreti Muhammed ümmetinin yeridir. Kıyamet haktır, sırat haktır derler, hepsini bilirler fakat amel etmezler. Cehennem o kimselerin yeridir dedi. Ey Ruhullah, cehennemin içi yılanlarla ve çıyanlarla doludur. Beni cehenneme götürdüler. Yılanlar ve çıyanlar bana doğru yöneldiler. Kaçacak yer yok, çare bulamadım. Her biri gelip bir yerimi dişledi. Onların zehri bin yıl kadar gitmedi. Allahuteala bana yetmiş deri vermişti. Arasına yılanlar ve çıyanlar doldurmuştu" (Toker ve Uygun, 2017, s. 84).

“Cehennemin yedi tabakası vardır. Bu tabakalardan en yükseği Cehennem'dir ve Muhammed Peygamber'in ümmeti içindir. İkinci tabakanın adı Latha'dır ve Hristiyanlar içindir. Üçüncü tabakanın adı Hutame'dir ve Yahudiler içindir. Dördüncü tabakanın adı Sair'dir ve İblis ile onun konukları içindir. Beşinci tabakanın adı Sakar'dır ve kıyamet gününü inkar edenler içindir. Altıncı tabakanın adı Cahim'dir ve firavunlar içindir. Yedinci tabakanın adı ise Haviye'dir ve o ateşin en şiddetli tabaka olduğu yer olup münafıklar için ayrılmıştır" (Padwick, 1930, s. 60-61).

Anadolu sahasında da yazılan diğer metinlerde bu ayrıntıların bulunmayışına ise Mehmet Erol şu şekilde bir açıklama getirir:

"Tatar sahasında Cehennem olgusu kompleks bir biçimde verilirken (Cehennem, Cehim, Hutame, Sair, Lezâ, Sakar, Haviye), metinde de görüldüğü gibi Anadolu çevresi manzum metinlerinde daha ayrıntısız verilmiştir. Yüksek bir kültür çevresinde Türkçe'ye kazandırılan eser, halk arasında taşınırken bu kompleks yapısından, kitabî teferruatlardan arındırımış olarak karşımıza çıkar" (Erol, 2006, s. 842). 
Özellikle manzum metinlerde bu tabakalandırmaya rastlanılmaması ve manzum metinlerin mensurlara göre daha az ayrıntı barındırması da Erol'un düşüncelerini destekler mahiyettedir. SÇ nüshasından farklı olarak manzum metinlerde bu tabakaların yerine yendiğinde hararet veren zakkum ağaci ${ }^{35}$ (Daşdemir, 410, Padwick, 61) ve zehirli kadeh motifi işlenir (Tansel, 1970, s. 260; Cumbur, 1977, s. 48; Önler, 1991, s. 379-380; Merhan, 2013, s. 3144, Padwick, 1930, s. 61).

Mısır'daki Yahudi-Arap yazmalarında ise cehennemin tabakaları ve bu tabakalarda bulunanlar Türkçe metinlerden oldukça farklıdır. Bu metinlerde ilk tabaka Hristiyanlar, ikinci tabaka kıyamet gününü inkâr edenler, üçüncü tabaka yıldızlarla ve kara büyüyle iş yapanlar, dördüncü tabaka Allah'tan başkasına tapanlar, beşinci tabaka putlara tapanlar, altınc tabaka inanmayanlar, yedinci tabaka Cehennem ise Allah'a inanmayan ve onun isteğine göre davranmayanlar içindir (Ørum, 2017, s. 59). Bu sınıflandırmalarda dikkat çeken, diğer nüshalarla kıyaslandığında bu versiyonda Yahudiler için ayrılmış bir tabakanın bulunmamasıdır. Ayrıca bu metinlerde de cehennemde acıkan ve susayan Cümcüme'ye verilenler Türkçe metinlerdeki zakkum ağacı ve zehirli kadeh motifiyle benzerlik gösterir. Ancak burada öne çıkan, Yahudi-Arap temelli anlatıdaki coğrafi ayrıntılardır. Örneğin yediği ağacın meyvesindeki acılığı anlatmak için Cümcüme Sultan, yaşanılan coğrafya, ait olunan din ve kültürün metin yazımına etkisini gösterir bir şekilde, şu benzetmeyi yapar: "Sokotra'daki ${ }^{36}$ ebucehil karpuzu ve baldıran zehirinden biraz daha acı" (Ørum, 2017, s. 63).

\subsubsection{Dünyaya Dönüş ve Anlatının Sonu}

Anlatıların hepsinde Cümcüme Sultan bir kuru kafa olarak dünyaya geri gönderilir. Bunun sebebi ise çoğunlukla dünyada iken çok cömert bir hükümdar olması ve yetimleri, yoksulları, dervişleri yedirip içirmesidir. Cehennemde bir müddet kaldıktan sonra dünyaya kuru kafa olarak dönen Cümcüme Sultan, İsa Peygamber ile karşılaşana dek bu şekilde yaşar.

“Hak Teâlâ Hazretlerinden ferman geldi kim siz anı mihnet içinden çıkarın azaptan kurtulsun dedi siz anın küfrüne bakman kim ol kendi ehline gayet kerim idi hem fakirleri sever idi işi miskinler ile idi tahtında adl ider idi ol dem beni yeryüzüne getirdiler" (SÇ, v. 128b).

Hüsam Kâtib'in anlatısı bu noktada SÇ ile uyumludur (Erol, 2006, s. 836). Daşdemir'in yayınladığı metin ile Çağatayca metinde ise "açları doyuruncaya kadar yemek yedirdiği, kaftanı olmayanlara kaftan verdiği, fakirlere altın para gönderdiği, mazlumlara adaletle davrandığı, kimseyi kapısından çevirmediği için cehennemden çıkarılıp melekler tarafından

35 Zakkum ağacı motifine ayrıca Çağatayca Cümcüme-nâme'de de rastlanmaktadır (Toker ve Uygun, 2017, s. 84).

36 Sokotra Yemen'e bağlı dört adadan ve Arap Yarımadası'nın güneyindeki adacıklardan oluşan bir bölgenin adıdır. Farklı bitki türlerine ev sahipliği yapmasıyla dikkat çeker. Coğrafi olarak Mısır'la çok yakın olmasa da bu iki bölge birbiriyle irtibatıdır. 
İsa Peygamber'in yolunun üzerine bırakılır çünkü İsa'nın Cümcüme hakkındaki duası Allah tarafından kabul edilecektir" yazmaktadır (Daşdemir, 2015, s. 411; Toker ve Uygun, 2017, s. 85). Manzum nüshalarda ise neden affedilip bir kuru kafa olarak cehennemden dünyaya gönderildiğine ilişkin bilgi verilmez, yalnızca cehennemden çıkarılıp "yol üstüne bırakıldığı" söylenir (Tansel, 1970, s. 260; Cumbur, 1977, s. 49; Önler, 1991, s. 380; Merhan, 2013, s. 3145; A, v.79b; B, v. 24b). Attâr'a atfedilen metinde de Cümcüme'nin niçin dünyaya geri gönderildiğine değinilmez. Kuru kafa cehennemde azap çekerken, bu nüshalarda olduğu gibi, birdenbire dünyaya gönderilir (Erol, 2006, s. 836).

Anlatının sonunda Cümcüme Sultan, İsa Paygamber'in duası ile tekrar bir insan şeklini alır ve bir süre Allah'a inanan mümin bir kul olarak yaşar ve her canlı gibi ölür. Anlatılardaki ana tema İsa Peygamber'in dua etmesi, Cümcüme Sultan'ın genç ve yiğit bir erkeğe dönüşmesi, Allah'a ibadet ederek bir müddet daha dünyada ömür sürmesi şeklindedir. Cümcüme'nin dua istemesi, dünyada kalma süresi, dönüştüğü kişi hakkında yazmalarda farklı versiyonlar bulunmakla birlikte ana yapının aynı kaldığı görülür. Örneğin SÇ nüshasında İsa Peygamber bir dileğinin olup olmadığını kuru kafaya sorar. $\mathrm{O}$ da dünyaya dönerek Allah onu cehennemden azad ettiği için birkaç yıl şükretmek istediğini söyler. Bunun üzerine İsa Peygamber onun bir bedene kavuşması için dua eder ve Allah da bu duayı kabul ederek Cümcüme'yi ölmeden önceki hâliyle yeniden yaratır. ${ }^{37}$ Cümcüme, İsa Peygamber'e iman eder ve Kudüs'e giderek burada bir kaya deliğinde tam yetmiş yıl Allah'a ibadet eder ve ölür:

"İsa eyitdi iy kuru baş hiç Allah Teala Hazretinin katında bir hacetin var mıdır eyit dedi derhal ol kuru baş eyitdi ya Nebiyallah benüm hacetim oldur ki geri dünyada bir kaç gün diri olam Hak Teala beni azad etdiğime şükürler edip bir kaç yıl ibadet edeydim dedi ol dem İsa el getürüp dua eyledi münacat kabul edici ol Rabbü'l-alemine arz-ı hacat eyledi didi kim ya sami'ul-esvat Hazretinden dilerim ki bu başda aza bitürüp can verip ol ne suretde idiyse kudret Issı ber-kemal geri evvelki gibi suretünde yaradasın dedi Hak Teala inayet edip evvelki suretine girip andan İsa Peygambere iman getirdi Hazret-i İsa iman telkin eyledi ol dem dahi eyitdi lâ İlâhe illallâh İsa Ruhullâh didi andan sonra Kudüs vilayetine varıp bir kaya deliğine girip ibadete meşgul oldu tamam yetmiş yıl ibadete meşgul olup ahir iman ile hatm olup rahmete ulaşdı" (SÇ, v. 128b-129a)

SÇ nüshası ve Hüsam Kâtib'in metninde İsa'nın "Bir dileğin var mı?" sorusu üzerine yeniden insan olmayı dileyen ve İsa'ya iman eden Cümcüme Sultan'ın diğer versiyonlarında İsa'nın böyle bir sorusu yoktur. ${ }^{38}$ Cümcüme, İsa'dan kendisine şefaat etmesini, Allah'ın

37 İsa Peygamber'in "yeniden diriltme, yaşam verme" gibi özelliklerinin edebi anlatılarda sıklıkla vurgulandığı bilinmektedir. Cümcüme Sultan anlatılarındaki İsa Peygamber'in diriltme motifi hakkında bkz: Daşdemir, 2015, s. 400-404.

38 Muhtemelen bu, Cümcüme'nin Allah'ın kendisini Hazreti İsa'nın duasıyla affedeceğini bilmesinden kaynaklanır. Bkz: Toker ve Uygun; 2017, s. 85. Ayrıca diğer manzum nüshalarda da İsa Cümcüme'ye bir dileği 
onu yeniden diriltmesini ve Hazreti Muhammed'e iman edip Allah'a kulluk etmeyi diler. Cümcüme seksen yıl geceleri namaz kılarak gündüzleri oruç tutarak yaşar ve imanlı bir şekilde ölüp cennet ehlinden olur (Daşdemir, 2015, s. 412; Toker ve Uygun 2017, s. 86). Cümcüme Sultan'ın adı, görüntüsü ve dünyada kalma süresi de nüshalarda çeşitlilik gösterir: Cümcüme ölmeden önceki suretinde, gayet yakışıklı ve yiğit bir erkek olarak, yeniden diriltilir ve kırk sekiz yıl Allah'a ibadet eder (Cumbur, 1977, s. 50; Önler, 1991, s. 381; Tansel, 1970, s. 261; A. v.79b-80a; ); Cümcüme yakışıklı ve yiğit biri olur ancak dünyada ne kadar daha yaşadığı bilinmez (Merhan, 2013, s. 3145-3146); Cümcüme genç bir delikanlı olarak yeniden yaratılır, İsa Peygamber ona Müslim adını verir ve yüz yıl Allah'a ibadet ederek yaşadıktan sonra ölür ( $B$, v. 25a); Cümcüme genç bir delikanlı olarak yeniden yaratılır ve sekiz yıl Allah'a ibadet ettikten sonra ölür (Padwick, 1930, s. 62).

Yahudi-Arap yazmalarında ise Cümcüme'nin bir tabut içinde yirmi dört yıl azap çektiği ve daha sonra "Allah'ın verdiği izin ile" cezasının sona erdiği anlatılır ancak Türkçe metinlerde yer alan İsa'nın duasına ve tekrar insan şekline dönüşmesine bu anlatıda rastlanmaz. Kuru kafa tıpkı Kutsal Kitap'ta, Sculpture'da, yazdığı gibi yetimlere, dullara, fakirlere ve çaresizlere iyilik yapmaktan başka hiçbir şeyin öldükten sonra insana fayda vermediğinden bahseder ve anlatı dualarla son bulur (Ørum, 2017, s. 69-73).

\section{SONUÇ}

İlkyazılı versiyonuna 11. yüzyılda Ebu Nuaym el-İsfahânî'de rastlanan ve bir kuru kafanın Hazreti İsa ile konuşmasını konu edinen kuru kafa anlatıları yazıya geçirilmeden çok daha önce, bir sözlü kültür ürünü olarak Arap edebiyatında yer alıyordu. Kutsal kitaplarda yer almayan bu anlatı zamanla birçok dilde ve kültürde yeniden yazıldı. Çoğunlukla ana teması farklılık göstermemekle birlikte anlatı, yeniden yazıldığı kültüre ve coğrafyaya göre bazı hususiyetler kazandı. Kimi zaman İsa ile kuru kafanın karşılaştığı bölge isimleri kimi zaman İsa yerine Hazreti Ali'nin ana karakter olarak metinde yer alması gibi farklılıklar anlatının yeniden yazılırken üretildiği kültüre nasıl adapte edilmeye çalışıldığını göstermesi bakımından dikkate değerdir.

Hüsam Kâtib'in Attâr'a atfedilen bir eseri tercüme etmesi üzerinden Türkçeliteratüre giren Cümcüme anlatısı, bu dilde de manzum ve mensur şekillerde birçok defa yeniden yazıldı. Genellikle cönklerde ve destanların yazıldığı mecmualar içinde bulunan bu versiyonlar, anlatının okur kitlesi hakkında da bir fikir vermektedir. Bu yazmalarda çoğunlukla imla bozuk ve vezin kusurludur. Ana temada belirgin bir fark olmamakla birlikte bu nüshalar, Cümcüme Sultan'ın ölüm şekli, Azrail ve cehennem tasvirleri, zaman ve mekâna dair verilen bilgiler gibi bazı konularda farklılık gösterir. Arap ve Yahudi-Arap kökenli versiyonlardan ise cehennem tabakaları ve bu tabakalarda yer alan insanlar gibi spesifik konularda ayrışır. Bu farklıı̆̆ın sebebi de yine anlatıların oluştuğu kültürel atmosferdir.

olup olmadığını sormaz: Bkz: Merhan, 2013, s. 3145; A. v. 79b; B; v.25a; Tansel, 1970, s. 261; Cumbur, 1977, s. 50; Önler, 1991, s. 381. 
Hüsam Kâtib'in Cümcüme Sultan eserinin Anadolu Türkçesine bir çevirisi olan Sermet Çifter Kütüphanesi'ndeki yazmanın kendi kaynak metnine sadık kaldığı ve manzum formdaki eserin "daha iyi anlaşılsın diye" sipariş üzerine mensur olarak çevrildiği görülür. Bu anlatıda bazı deyim ve davranışların Anadolu'ya uygun bir şekilde çevrildiği, metnin başarılı bir şekilde adapte edildiği görülür. Bu anlamda hem bir çeviri hem de bir adaptasyon olan bu metin tradaptasyon olarak tanımlanabilir.

Cümcüme Sultan anlatıları yahut İsa ile kuru kafa / kesik baş anlatıları kütüphane kataloglarında oldukça fazla yer tutar. Türkçe ve Arapça dışında başka dillerde yazılmış versiyonları da bulunan Cümcüme anlatılarının ayrıntılı bir şekilde incelenmesi, tasnif edilmesi, dünya edebiyatındaki yerinin ve etkileşim alanlarının tespit edilmesi ve yeniden yazım bağlamında ayrıntılı bir şekilde değerlendirilmesi gerekmektedir. Bu inceleme yapılacak çalışmalara mutevazı bir katkı sağlayabilirse işlevini yerine getirmiş olacaktır.

\section{TRANKRIPSIYON}

\section{Hāz̄ā Ḥikāyet[-i] Cimcime Sulțān 39}

\section{[120b] Bismillāhirraḥmānirraḥīm}

El-hamdü li'llāhi ‘ale'd-devām ve'ș-șalātü ve’s-selāmü ‘alā resūlihi hnayri'l-enām ve ‘alā ālihi ve așhābihi el-ikrām mā țala'u'ş-şark ve lema'mā el-berk fị z̧-ẓallām ve ba'de bir gün ol huan-ı 'ādil ü hāḳān-ı 'aḳıl Șāhib Giray Han bin Hācı Giray Han halleda'llāhu 'ale'l'ālemīn tārīh toḳuz yüz elli beşde iken hazīne kitābları içinde Cimcime Sulțān hịāyetin görmiş ki tārīh yedi yüz yetmiş yedide Hüsām Kātib Mog̉al dilince naẓm itmiş ammā bu 'acāyib ḥikāyet ü garāyib rivāyetdür ki oḳıup diñleyen Allāh Te‘ālā Hażreti pek kemāl-i ḳudretin istidlāl olur çün Ḥażret-i Han bu kitābı görüp buyurmuş ki varuñ bu kitābı eż‘afü’l‘ibād du‘ācımıza iledüñ Türkī dilince neṣr eylesün [121a] oḳıyup diñlemege āsān olsun diyüp göndermiş lā mā lā şerîf bu dahı ḳudreti yetdükçe ḳaleme getürdüm ümīzndür ki 'avn-i İlāhī birle tamām olduḳda șoñra ḳabūl de vāki' olup pādişāhuñ naẓar-ı 'ināyetiyle mukārin ${ }^{40}$ olam zīrā pādişāhlaruñ 'ināyet naẓarı Haḳk Te‘ālānuñ raḥmetidür Allāhümme yessir $\Pi^{41}$ ba'dehu ol kitāba naẓar itdüm kim mü'ellif-i kitāb eydür anı cemmen bāḳ̄ bilenler gelüñ işidüñ dünyā işi nedür bilüñ çün bu 'ālem 'âḳıbet fānīdür içinde olanlaruñ bekāās yoḳdur pes bu işe işāret bize yeter bu 'ālem benüm diyenler yarın geçer evvel gelenler geçdiler șoñ ḳalanlar anı acdılar bunca evliyālar enbiyālar gelüp geçdiler

39 Eski Anadolu Türkçesi özelliklerini içinde barındıran bu metinde imla hatalarına sıklıkla rastlanılmaktadır. Bu çalışmada yanlışlıklar dipnotta gösterilmiş ve metin içinde kelimelerin doğru şekilleri yazılmıştır. Tekrar eden harf hataları çok fazla olduğundan gösterilmemiştir. Bazı kelime ve eklerin yazımında çeşitlilik görülür. İmladaki bu tutarsızlığı gösterebilmek için çeviri yazıda metindeki yazılış esas alınmıştır. Okumayı kolaylaştırmak için bazı heceler [] içinde eklenmiştir. Metinde okunamayan yerler * işaretiyle, şüphe duyulan kelimeler ise yanına (?) işareti konularak yazılmıştır. Arapça tabirlerin Türkçe çevirileri ise dipnotta gösterilmiştir.

40 Kelime şu şekildedir: بـ

41 "Allahım [bunu] benim için kolaylaştır." 
pādişāhlar gedālar ecel şarābın içdiler Ādem -'a. m.-42 biñ yıl 'ömür sürdi yazu ne ise gördi Nūḥ Peyǵamber -'a. m.- dahı țoḳuz yüz elli yıl 'ömür sürdi țūfāndan selāmet ile ḳurtulup āhır ecel derdine dermān bulmadı ve İbrāhīm Peyg̉amber -‘a. m.- nār-ı Nemrūdı gülistān görüp murādına irdi 'āḳıbet Cān̄̄i3 şerbeti virdi bu dünyāda kimesne bāḳ̄ ḳalmaz illā ki Rabbü'l-‘ālemīn ve ne ḳadar pādişāhlar ki [121b] geçdi her biri bu cihān mülkini benümdür didiler anlaruñ her birinüñ niçe yüz biñ 'askeri vardı tāc [u] taht șāhibi pādişāhlar

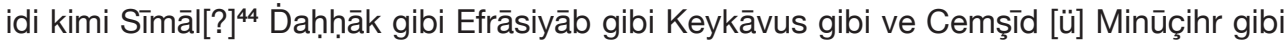
ve ‘Ād ü Hüsrev kimi Žülḳarneyn ve kimi Z̄āl ü Rüstem [ü] İsfendiyār gibi Nūşirevān-ı 'ādil kimi Sulțān Maḥmūd ve kimi İbrāhīm bin Edhem ${ }^{45}$ kimi faḳir [ü] ihtiyār (?) ${ }^{46}$ idi ve kimi Cengiz Han ve kimi Özbek Han ve kimi Hanbeg Han ve kimi Tohtamış Han ve kimi Hāà Giray Han ve kimi Mengli Giray Han 'aleyhimi'r-rahme ${ }^{47}$ ke emsāalihim ${ }^{48}$ bunlar gibi pādişāhlar bunca ni‘met-i nüzūl ḳul $[u]$ ḳaravaş $[u]$ at $[u]$ țon $[u]$ tāc $[u]$ taht $[u]$ māl $[u]$ mülkden ayrılup birer kefinlik bez alup gitdiler çünki dünyāya gelen ölür 'aklı olan aña göre tedārik ider bunca halḳ kim geldiler ḳara hạā birle yeksān oldılar şöyle kim her ḳadem yere bașarsın bir melik zülfinüñ ${ }^{49}$ yüzine bașarsın her yāsemīn bir aḳ maḥbūbuñ teni aġıdur ve her sünbül bir dilberüñ zülf-i siyāhıdur ve her lāle bir 'āşıḳuñ bag̉nı ḳanıdur pes bu ḳara yerde țoprak içinde yatanlaruñ kimi sulțān kimi ḳul kimi șagīir kimi [122a] kebīr kimi bay u kimi gedā kimi şeybu ü kimi pīr ü kimi cüvān her biriniñ ${ }^{50}$ hāli hemān Allāh bilür Hażret-i Allāh anlaruñ țopraġın yellere șavurup zerre żerre ${ }^{51}$ itmişdür şāh [u] gedā belürsüz olmışdur imdi bu sözüm bir meșel kim mișilsüzdür bilürsüz yag̉dan 'asel52 meger 'Īsā Peyǵamber -'a. m.- bir gün müsāfirlik kılup Şām mülkine geldi ittifāḳ bir merǵ-zār șaḥrā görindi ol șaḥrāda șular āb-ı revān ${ }^{53}$ olmış aḳar gelüp șu kenārında oturdı kudretu'lllāh birle naz̧ar iderken gözine bir ḳabir görindi içinde bir ölü ādem başı var emr-i îlāhī birle ḳararmış eti çürümiş ma'raları ${ }^{54}$ dökülmiş Hażret-i 'Īsā anı görüp 'ibret aldı eyitdi kim vallāhi bu ḳadar 'ömür sürdüm bunuñ gibi ölü baş görmedüm diyü temāşā eyledi alnına naz̧ar eyledi gördi kim iki sațır ${ }^{55}$ hațt yazılmış dimiş kim bu baş dünyāda biñ yıl 'ömür sürdi cümle ‘ömrinde 'āleme pādişāh ${ }^{56}$ oldı bundan șoñra gine dirilüp başından niçe nesneler

42 Metinde 'aleyhi's-selām kelimesinin karşılığı olarak bu kısaltmalar kullanılmıştır. Bu ibareler burada ve daha sonraki kullanımlarda metindeki şekliyle yazılacaktır.

43 Azrail kastedilmektedir.

Kelime şu şekildedir: 1 hu فه şeklindedir.

Kelime şu şekildedir:

"Rahmet onların üzerine olsun".

"Bunlar gibi"

ذ harfi ile yazılmıştır.

Ñ harfinden önce ي harfi yazılmıştır.

jharfi ile yazılmıştır.

Cümle tamamlanmamış intibaı vermektedir.

Tamlama nüshada bitişik şekilde yazılmıştır.

Kelime şu şekildedir: نفو ليح

illk hece uzundur.

Kelime mükerrerdir. 
geçüp 'āḳıbet cān murg̉ı ten ḳafesinden uçısardur dimiş ol dem 'T̄sā -‘a. m.- taḥayyürde ḳaldı biraz fikr itdi kim andan cān yüzin dergāha [122b] țutup eyitdi kim iy kāāir-i pürkemāl ḥażretüñden ḥācetüm budur ki bu başuñ aḥvālini kendü dilinden işitmek dilerüm didi ol sā'at Haḳk Te‘ālā Hażret-i Cebrā’T -‘a. m-[a] buyurdı kim var rūḥum 'T̄sāya benden selām eyle kim dahı Ādem yaradılmazdan evvel senüñ hācetüñ ben ḳabūl itmişüm Resūlüm 'ITsā șorsun ${ }^{57}$ ol ḳurı baş benüm ḳudretüm birle söylesün didi bu haberi 'Îsā -'a. m.- işidicek ḳurı baş yanına vardı eyitdi kim iy ḳuru baş ${ }^{58}$ bu dünyāda sen er miydüñ 'avrat

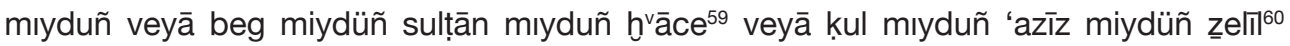
miydüñ Tengríi1 fermān[1] ile eyit didi ol ḳuru baş dilsüz iken ḳudret-i iliāhī birle söze gelüp eyitdi kim iy Tengri resūli diñle imdi benüm başumdan neler geçmişdür ben dünyāda bir ulu pādişāh idüm memleketüm ma‘mūr ni‘metüm bol idi ve taht-gāhum bir mu'aẓz̧am şehir idi kim uzunlıg̉ı beş günlük yol idi içi tuc idi țaşrasından gör ne heybet içinde gör ne cennet idi içinde 'adl idüp kimseye güç itmez idüm ve ḳırk vezīrüm var idi her biri ‘āḳıldāne ve ehl-i tedbīr idi ḥekīm-i [123a] ḥāžı ${ }^{62}$ gibi hemān ölüy[i] diri ḳılmazlardı ve daḩı on sekiz biñ mu'teber beglerüm vardı her gün gelüp baña baş ururlardı eger bir hüüüm itsem bir gün şarḳdan ġarba irişür idi ve her ḳaçan atlansam yüz biñ ḳulum var idi șag̉umda [vü] șolumda yürürlerdi șaçları içinde yüzleri güneşe beñzerdi ve üç biñ șāfi ațlas ${ }^{63}$ giyerdi öyünleri (?) ${ }^{64}$ ve ke[me]rleri șāfì murașșa‘ idi ve ellerinde birer kāse filori țutarlardı hāācetüm olduḳça anlardan alup nișār ider idüm ve on biñ ḳulum yeşil ațlas donlu aḳ yāsemīn tenlü ve hüsn içinde bī-mișl idiler ellerinde envā' dürlü silāḥlar țutarlar idi ve on biñ ḳulum aḳ ațlas giyerlerdi ak ḳıratlara binerlerdi ve on biñ ḳızıl aṭlas țonlu ḳullarum varıdı ve on biñ Habeşi ḳullarum var idi her biri hııžmetlerinde hāżırlar nāẓırlar ḳāyimler idi ve dahı on biñ maḥbūb ḳılarum var idi ve on biñ hatunlarum vardı her biri hüsn içinde bī-mišl ü bī-naẓīr idi-kim ḥūrīere beñzerdi bunlaruñ her biri beni [123b]görmege zaār iderleridi biñ hvāanende ${ }^{65}$ vü sāzendem varıdı kimi çeng ü kimi ḳānūn u kimi ḳopuz u kimi țanbūre ve kimi ‘ūd u kimi kemānçe ve kimi nāy ve kimi 'anḳā (?) ${ }^{66}$ her biri bir dürlü sāz çalarlardı ve'l-hāọsı yüz biñ 'askerüm var idi birine biñ kişi muḳābil durmazdı ve biñ pāre muḥkem ḳal'am var idi kim biri düşmāndan bī-ḩaber idi aña göre māl bī-ḥadd ü bī-ḳıyās idi ve ilüm vilāyetüm toḳluḳ u ganīlık idi ve özüm tāze cüvān idi ve pādişāh og̉lı pādişāh idüm heybetde arslan heybetlü insān idüm adıma Cimcime Sulțān dirlerdi ḥüsnüme halḳum ḥayrān idi yüzümi

57 wharfi ile yazıımıştır.

58 Metinde kimi zaman ḳurı baş kimi zamansa ḳuru baş şeklindeki kelimenin yazımı çeviri yazıda çeşitliliği göstermesi için metindeki haliyle yazılmıştır.

59 خو خوخه 5 şeklindedir.

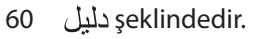

61 Kelime şu şekildedir: تَكي دئ. Bu sebeple çeviri yazıda Tañrı değil Tengri şekli kullanıldı.

62 حادق şeklindedir.

63 Kelime yazmada şu şekildedir: $\iint^{a} 3$

64 Kelime şu şekildedir: اوخونمكي

65 خو نو 64 şeklindedir.

66

Kelime şu şekildedir: 
gören ādem zīrā yüzüm güneşe alnum aya ve beñlerüm yılduza ve ḳaşum hilāle beñzer idi her yerde ž [ū]-fünūn idüm ve'l-ḥāṣıl ol ḳādir-i żü'l-celāl baña ol ḳadar tevāżu‘ virmiş idi kim ta'bīri mümkin degül idi 'ādetüm bu idi kim bir miskīn-i ġarīb gelse aña murādınca en‘ām gönderür idüm ve ța'āmı faḳirlerle yer idüm halḳ içinde bu hạal ile meşhūr idüm ve mațbahumda her gün biñ deve vü biñ [124a] at u biñ öküz ü üç biñ ḳoyun boġazlanur idi pişer idi işde bunuñ gibi ulu pādişāh iken öldükden ${ }^{67}$ șoñra dünyāya gelmemiş gibi oldum çün ol ḳuru baş Haḳk Te‘ālā ḳudretiyle kendü ḥālin i'lām eyledi andan 'Īsā -‘a. m.- eyitdi iy Cimcime Sulțān āh̆ır ${ }^{68}$ vaḳtüñde cānuñı ne hạal ile virdüññ ${ }^{69}$ baña anı hiikāyet eyle cān virdükden ${ }^{70}$ șoñra seni kimesne ohşadı mı yohsa urdı mı cennete mi gönderdiler yohsa cehenneme mi gönderdiler andan ḥālüñ nice oldı ol ḳuru baş gözsüz iken ḳan yaş dökdi ve dilsüz iken dile gelüp āh idüp bu gizden ser-encāmın 'T̄sā Peyġamber -‘a. m.-a eyitdi yā Nebīyya'llāh ne 'aẓim nesneden su'āl itdüñ anuñ cevābın virmege țāḳatüm yoḳdur ammā biñde birin söylesem olur diyüp eyitdi bir gün șafā-yı ḳalble meclis ḳurup otururdum 'Ţş u 'işret [ü] șafāya meşg்ūl idüm ol gül yüzlü sünbül zülüflü hatunlarum yanumda șaǵ u șol oturmışlar idi ol huūb yüzlü merḡūb sözlü cāriyelerüm kimi tācum țutar idi ve kimi ḳaftānum [124b] țutarlardı bu ḥālde iken gözime bir özden maḥbūb gözüme düş oldı göñlüm aña düşdi ol nigārı yanıma alup bir halvet-hāaneye vardum zeveṿ itmege meşḡūl oldum ittifāk maḥremlerden biri gelüp eyitdi ḳapuya bir faḳir geldi sizden iṇsān u in‘ām diler didi ol dem ben hod dil-dāre meşgūl idüm gözüme 'ālem görinmez idi eyitdim ki iy aḥmaḳ şimdi iḥsān zamānı mıdur didüm meger ol ḳul benüm sözümi ol faḳire dimişdi anuñ göñli yıḳılup gitmiş șoñra halvet-hāneden ḳalḳup ol faḳiri çoḳ arandum bulmadum andan gusl idüp pāk olmak murādum idi șoyunup başuma bir iki țas șu dökince bir 'illet z̧āhir oldı n[ā]çāâr başuma çoḳdı gözüm ḳarardı 'aḳlum gitdi yere düşdüm ḥālet-i nez'a vardum ol dem ḳullarum beni yerden götirdiler tahtuma bindürüp yaturdılar ol gice șabāḥa degin yanumda oturdılar 'ale'ș-șabāḥ vezīrlerüm ḥekīmlerüm getürdiler şol ḳadar 'ilāc itdiler kim hergiz dermān bulmadum devā itdüklerince derdüm [125a] dahı ziyāde oldı meger āhır vaḳtüm yetmiş imiş çün ta‘alluḳātum beni bu ḥālde görüp nevḥa vü zārī ḳılup feryād u figāan itdiler anlar āh u fiḡānda ben kendü ḥālümde il vilāyet ü māldan fārig oldum yedi gün ḩasta yatdum dermān bulmadım nā-gāh gözüme bu cihān bir ulu șaḥrā görindi ol dem ferşümde bir ulu kimesne çıḳa geldi altı yüzi var gözleri od gibi yanar ve iki ḳanadı şark ile garb arasında țutmuş anuñ adına 'Azrā'̄l dirler imiş bir elinde bir harbe var ve bir elinde bir ḳadeḥ var kim andan içen hergiz feraḥ görmez andan ḳorḳup su’āl itdüm senüñ yüzüñ neden altıdur biri yuḳaru vü biri aşaġa vü biri ardıña vü biri altuña vü biri șag̉nña vü biri șoluñadur didüm ol eyitdi ḳaçan üstün yüzümi açsam gökde melekler cān virür ve șaǵ yüzümi açsam evliyālar enbiyālar cān virür ve anlaruñ güzīdesi Habību'llāh Muḥammed Muștafā ol nübüvvet ma‘deninüñ gevheridür ve kerāmet kānınuñ cevheridür Haḳk Te‘ālā on sekiz biñ ‘ālemi anuñ muhabbetine yaratdı [125b] dünyāda Resūlü Rabbi’l-

67 ş̧ اولدوقدن 68 reklindedir.

68 Mükerrer yazılımıştır.

69 Kelimenin son hecesinde "و" sesi gösterilmiştir.

70 ş ويردقدن 
'ālemīndür āhıretde şefi'ü’l-müžnibīndür ve șol yüzümi açsam kāfirler cān virür ve aşag̉a yüzümi açsam cümle yer halḳı cān virür didi ben eyitdüm bu elüñde ḳadeḥ ile harbe nedür didüm ol dem 'Azrāyil -'a. m.- ḥarbesin gögsüm üzerine ḳodı dahı ḳadeḥini iç didi ḳorḳıyla ol ḳadeḥden içdüm ol sā‘at cān ḳuşı tenüm ḳafesinden uçdı șoñra beni bir sā‘at kendü evümde ḳomadılar götirdiler sürüp ḳabrüme getürdiler bir zamāndan gözüm açdum gördüm ki tenüm țopraḳda yatur beni bir pāre beze șarmışlar eyitdüm ki iyvāh bunca mālumdan baña bir pāre bez degmiş ḥayf kim taḥt [u] bahttan at [u] țondan māl [u] mülkden ḳul [u] ḳaravaşdan [u] yoldaşdan oǵlı ḳızdan ayrıldum dirken anı gördüm ki iki heybetlü kişi ḳabir dĩvārını yüzüp ḳarşuma geldiler ḳorḳumdan siz kimlersüz diyü șordum eyitdiler kim biz Münker ${ }^{71}$ ü Nekīrlerüz diyüp ol dem kefenümden bir pāre bez üzdiler ne ḳıldum ise aña yazdılar ve dahı boynuma așaḳodılar eyitdiler kim bu senüñ 'amelüñdür didiler [126a] Bunuñ cezāsın gör didiler ve dahı kendiler ol dem iki kimesne dab̧ı geldi ellerinde oddan 'amūdları vardur gelüp beni ḳısac ile muḥkem țutup eyitdiler kim iy Mecūsī Tengrüñ kimdür eyit yoḳ dirseñ ‘amūdı yedüñ didiler anlara ben cevāb viremedüm ol dem beni oddan 'amūdlarla muḥkem dögdiler andan zebānīer gelüp alnuma damǵa bașdılar andan oddan bir zincīr getürdiler boynıma bag̉ladılar yüzüm üzerine süriyüp țamuya ḳodılar od ıssısından içim ḳızdı çaġırup șu diledüm zaḳụūm getürdiler içdüm dahı beter içim ḳızdı ve beni ol yirden götürdiler yetmiş arşun zincīr getürdiler aǵzımı açup içine ucı șoḳup eñsemden çıḳardılar dahı yüzüm üzre süriyüp bir țamuya dahı iletdiler bir niçe kerre dahı anda ḳaynatdılar ve'l-ḥāșıl yedi țamu ser-te-ser gezdürdiler her birinde dürlü dürlü 'azāāblar eyitdiler pes her kim ki Haḳk Te‘ālānuñ ni‘metin yiye emrine ițā'at itmeye ol şekāvet 'alāmetidür ne‘ūžü bi’llāh çünki Ḥażret-i 'Īsā -‘a. m.- anı işitdi [126b] derdile āh idüp bir niçe āh idüp ag̉ladı cān [u] göñlinden țā'ate 'ibādete bel baǵladı andan eyitdi kim yā Cimcime ol yedi țamu[y]ı niçe gördüñ anı baña ḥikāyet eyle kim her birinde ne vardur ve degme țamuya kimler girerler didi ol ḳuru baş eyitdi yā Rūḥa'llāh țamu yedi ḳatdur birbirinden ıssısı ziyādedür aşag̉a țamunuñ adı Hāviyedür anuñ 'az̄ābı cümlesinden eşeddür aña münāfıḳlar girer andan yuḳaru ikinci țamunuñ adı Sakardur aña Yehūdiler girer ve üçünci țamunuñ adı Huțamedür Nașrānīler anda girer ve dördinci țamunuñ adı Laz̧z̄ādur anda Mecūsiler girer ${ }^{72}$ ve beşinci țamunuñ adı Sa ‘îrdür aña ehl-i kebā'ir girer ve altıncı țamunuñ adı Cahīm dür aña kežžāblar girer yedinci țamunuñ adı Cehennemdür 'azāabı cümlesinden azdur aña Muhammed ümmetinüñ tevbesiz gidüp şefā'at irişmeyenler[i] girer ${ }^{73}$ bu her țamunuñ țaşı ya ḳar gibidür od ıssısından irüyüp ḳalay gibi

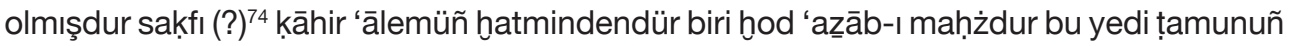
her birinde dürlü dürlü 'az̄āblar vardur hergiz birbirine beñzemez [127a] anda bir bölük ḳavim gördüm kim ag̉ızlarından iriñler aḳar şöyle murdār ḳoḳar kim cehennem anlardan incinür meger anlar ḥarām yiyenler imiş yine bir ḳavim daḩı gördüm ayaḳları yuḳarı başları aşag̉a 'az̄āb çekerler meger anlar nebilik da'vāsın ḳılup ayru baş çekenler imiş dahı bir

71 Metinde "Münkīr" şeklindedir.

72 şeklindedir.

73 ş şرور كرور

Kelime şu şekildedir: نقفئ 
ḳavim gördüm gözleri yoḳ meger anlar yalan yire țanıḳlık virenler imiş yine bir ḳavim dahı gördüm gözleri vü elleri vü ayaḳları vü dilleri yoḳ meger anlar ẓālim ḥākimler imiş dahı bir bölük ḳavim gördüm dilleri eñselerinden çıḳmış meger anlar țog̉ı sözi yalan söyleyüp halḳa bühtān idenler imiş yine bir ḳavim dahı gördüm kim zebāniler yüzlerine țamġalar bașarlar meger anlar māl [u] menāl ıssı ġanī devletlü imiş mālları zekātın virmezler imiş eger bir kişide biñ hüner olsa çoḳ degül bir bahilüñ bir hasīsüñ biñ hüneri bașar nitekim dimişlerdür bir sahāvet biñ 'aybı örter 'ālemde ādeme āb kim dirler kişiye āb-ı ḥayāt kim eyü nām ḳazanmaḳdur dahı bir bölük ḳavim gördüm yañaḳları yalıñsuz āteş idi Haḳk Te‘ālā ḳudretiyle bir olurdı meger bunlar nā-ḥaḳk [127b] yerde başlar kesüp ḳanlar dökenler imiş yine bir ḳavim gördüm yüzlerine dag̉lar bașarlar meger anlar dünyāda ‘ömür sürüp Allāh Te‘ālā Ḥażretinüñ ni‘metlerin yiyüp içüp şükrin itmeyenler imiş yine bir 'acāyib ḳavim gördüm cümle halḳdan baña ol 'az̄āb yaman geldi zīrā cümlesi mestūr olmış yalıñ açık başları șaçları żell muḥtāc ‘uryān [u] büryān olmış tenlerinde ḳan iriñ aḳar cümle cehennem halḳı anlara baḳup ol 'az̄ābdan Allāh Te'ālā Ḥażretlerine șıgınurlar meger bunlar yedi iḳাim[e] pādişāh olan kimesneler imiş kim her günde kaç dürlü libās giyerlerdi ve faḳir fuḳarāyı sevmeyüp țamdan sürüp ța'ām yedürmezlerdi ve faḳîrleri giydürüp ölüye kefin virmezlerdi dünyā mālı bizümdür șanurlardı bu sözleri Hażret-i 'İsā Peyġamber -'a. m.- ol ḳuru başdan işitdi āh idüp ag̉ladı andan ol ḳuru baş eyitdi șoñra bir ḳaç melekler gelüp beni ol yerden aldılar yüzüm üzre sürüyüp vādīye iletdiler ol vādī gāâyet

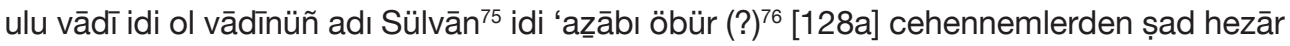
elvān imiş andan ötede bir tābūt gördüm baña eyitdiler kim gel gir bu tābūt içine otur didiler ol dem tābūta girdüm oturdum nā-gāh gözüme üç bölük ādem görindi ben bunlardan șordum kim siz ne kişilersiz didüm bunlar eyitdiler biz dünyāda māl [u] mülk ıssı ulu sulțānlar idük şimdi gör hạalümüzi ne oldı didiler eger bu aḥvāli bize olacag̉ın bileydük dünyāda aç żelī geçinürdük kāşki cihānda pādişāhlar olmaḳdan faḳīr-hāā olayduk āh idüp ag̉laşurlar çünki cihān sulțānlarınıñ șoñı budur vay aña kim cihānda pādişāh olup gaāfil yatasın dab̧ı ol tābūt içinde gördüm ki 'aḳrebler [ü] yılanlar u çayanlar anları șoḳarlar etleri ol yılanlaruñ dişlerinde ḳalur hemān etleri doḳanduġı gibi girü bir sā'atden soñra yeñiden etler bitüp ol 'aḳrebler gine yirler idi beni tābūt içine ḳoydıḳları gibi ol yılanlar u ol 'aḳrebler ü ol çayanlar ol 'az̄āb[1] gelüp baña dahı itmege başladılar ben ag̉layup zārī zārīi iñleyüp eydürdüm ki [128b] iy 'aceb baña şefā'at ḳaçan ola dir idüm ammā dünyāda ben ne etsem baña dahı anı 'az̄āb iderlerdi ne sözüm kimse işidürdi ve ne zebānīler aman virüp ḳurtılurdum ve ne bir çāre bulabilürdüm ve ne 'az̄ābum eksilür idi ol hạālde iken Haḳk Te‘ālā Hażretlerinden fermān geldi kim siz anı miḥnet içinden çıḳaruñ 'ażābdan ḳurtılsun didi siz anuñ küfrine baḳmañ kim ol kendü ehline gāyet kerīm idi hem faḳ̂̄rleri sever idi işis ${ }^{77}$ miskīnler ile idi tahtunda 'adl ider idi ol dem beni yer yüzine getürdiler ol dünyāda biñ yıl 'ömür sürdüm soñra țamuda dört biñ yıl 'az̄āb çekdüm işde

75 Diyarbakır'ın doğusunda eski adı Miyafarikin olan yer.

76 Kelime şu şekildedir:

77 "işini" şeklindedir. 
böyle bu șaḥrāda ${ }^{78}$ getürdiler ḳodılar Hażret-i 'Īsā -‘a. m- eyitdi hīç ol zamānda size peyǵamber ya‘nī nebī geldi mi didi ol ḳuru baş eyitdi ol vaḳit İlyās Nebī -‘a. m.- gelmiş idi ne aña uyduk ve ne Tengriye inanduk özümüz egriyse kendü ḳanumuza kendümüz girdük ol sebebden dört biñ yıl 'ažāb çekdüm didi andan 'Īsā -'a. m.- eyitdi iy ḳuru baş hīç Allāh Te‘ālā Ḥażretinüñ ḳatında bir ḥācetün var mıdur eyit [129a] didi derhạāl ol ḳuru baş eyitdi yā Nebiyya'llāh benüm ḥācetüm oldur ki girü dünyāda bir ḳaç gün diri olam Haḳḳ Te‘ālā beni āzād itdügine şükürler idüp bir ḳaç yıl 'ibādet ideydüm didi ol dem ‘'Tsā -'a. m.- el getürüp du'ā eyledi münācāt ḳabūl idici ol Rabbü'l-'ālemīne 'arż-ı ḥācāt eyledi didi kim yā Sāmi'a’l-așvāt ${ }^{79}$ Hażretinden ${ }^{80}$ dilerem ki bu başda a‘żā bitürüp cān virüp ol ne șūretde idiyse ḳudret ıssı ber-kemāl girü evvelki gibi șūretinde yaradasın didi Haḳ Te‘ālā 'ināyet idüp evvelki șūretine girüp andan 'Īsā Peyǵambere īmān getürdi Hażret-i ‘Tsā îmān telḳin eyledi ol dem dahı eyitdi lā Ilāhe illa'llāh 'Tsā Rūḥu'llāh ${ }^{81}$ didi andan șoñra Ku düs vilāyetine varup bir ḳaya deligüne girüp 'ibādete meşgūl oldı tamām yetmiş yıl ‘ibādete meşǵūl olup āhır îmān ile hatm olup raḥmete ulaşdı imdi iy 'aż̄z sen bu sözleri fehm eyle yahşı yamandan fark eyle gör kim bunca pādişāhlar gelüp geçdiler [129b] her biri ecel şarābın içdiler pes bu cihānda kimse bāḳi ḳalmaz ancaḳ ādeme ḳalacaḳ bir yahşı nāmdur imdi gāfil olma Tengri virdügi rızḳa şükr idüp Hakḳ ismini žikr eyle ve bu hatm olmış ve hatm eylemiş Ḥüsām Kātib raḥmetu'llāhi 'aleyh raḥmeten vāsi‘aten imdi her kim bu kitābı oḳudup diñler Haḳk Te‘ālā hidāyet idüp raḥmet ide ve yazana dahıı bir du'ā ide Fātiḥa

Teşekkür: Bu makale Boğaziçi Üniversitesi Türk Dili ve Edebiyatı Bölümünde aldığım Rewriting and Examples in Old Turkish Literature dersinin ürünüdür. Bu vesileyle Prof. Dr. Nur Gürani Arslan'a, makalenin yayınlanması noktasında beni teşvik eden Prof. Dr. Hayati Develi'ye ve çeviri yazılı metni gözden geçiren Prof. Dr. Mehmet Fatih Köksal'a teşekkür ederim.

\section{KAYNAKÇA}

Albayrak, N. (1983). Folklorumuz ve Erzincan. Erzincan: Erdav Kitabevi.

Aydınlı, F. (2013). Cimcime Sultan-kuş sesleri/masallar-2. Ankara: Türkiye Diyanet Vakfı Yayınları.

Bastin, L. G. (2011). Adaptation. In M. Baker \& G. Saldanha (Eds.), Routledge encyclopedia of translation studies (pp. 3-6). London and New York: Routledge.

Brakel-Papenhuyzen, C. (2002). The tale of the skull: An Islamic description of Hell in Javanese. Bijdragen tot de Taal-Land- en Volkenkunde, 158(1), 1-19.

Bilge, M. L. (2006). Mustafa Paşa, Buşatlı maddesi. Türkiye Diyanet Vakfı İslam Ansiklopedisi içinde (C. 31, s. 344-345). Ankara: Türkiye Diyanet Vakfı Yayınları.

78 wharfli ile yazıımıştır.

79 wharfiyle yazılmıştır.

80 "Hażretüñden" şeklindedir.

81 "Allah'tan başka İlah yoktur ve İsa onun peygamberidir." 
Cumbur, M. (1977). Cimcime Sultan destanı. M. And, M. Cunbur ve Ş. Elçin (Ed.), Türk folkloru araştırmaları yıllığı 1976 içinde (s. 39-54). Ankara: Kültür Bakanlığı MFAD Yayınları.

Çınarcı, M. N. (2004). Bakü El Yazmaları Enstitüsü'ndeki Türkçe el yazmaları-I (Halk edebiyatı numuneleri). Türklük Bilimi Araştırmaları Dergisi, 36, 33-60.

Dağlı, Y., İşli, E. N., Serbest, C. ve Türe, F. (Ed.). (2001). Yapı Kredi Sermet Çifter araştırma kütüphanesi yazmalar kataloğu. İstanbul: Yapı Kredi Yayınları.

Dâstân-ı Cimcime Sultân.[El Yazması]. Milli Kütüphane Yazmalar Koleksiyonu 06 MilYz A 6823/6 numara.v. 22a-25a.

Dâsitân-ı Cimcime Sultân. [El Yazması]. Milli Kütüphane Yazmalar Koleksiyonu 06 Mil Yz A 3881/8 numara. v. 76a-80a.

Daşdemir, Ö. (2015). Düzyazı Şeklinde yeniden yazılan anonim bir cümcüme hikâyesi. Selçuk Üniversitesi Türkiyat Araştırmaları Dergisi, 37, 387-414.

Durmuş, T. ve Gürbüz, M. (2017). Nazımdan nesre anlatımın dönüşümü: Dâsitân-ı Ferruh u Hümâ Örneği. Divan Edebiyatı Araştırmaları Dergisi, 19, 147-168.

Erol, M. (2006, Nisan). Cimcime Sultan Destanı́nın Anadolu ve Tatar eş metinleri üzerine bir mukayese. 1. Uluslararası Türk Dünyası Kültür Kurultayı, İzmir.

Hāz̄ā Hikāyet-i Cimcime Sultan.[El Yazması]. Yapı Kredi Sermet Çifter Kütüphanesi. Nr. 156/2. v. 120b-129b.

İpşirli, M. (1994). Duâgû maddesi. Türkiye Diyanet Vakfı İslam Ansiklopedisi içinde (C. 9, 541-542). Ankara: Türkiye Diyanet Vakfı Yayınları.

Kalafat, Y. (2004). Anadolu'da ulu kadın kişiler ve halk inançları. Türk Kültürü ve Hacı Bektaş Velî Araştırma Dergisi, 32, $1-16$.

Kandemir, M.Y (2001). Ka'b el-Ahbâr maddesi. Türkiye Diyanet Vakfı İslam Ansiklopedisi içinde (C. 24, s.1-3). Ankara:Türkiye Diyanet Vakfı Yayınları.

Kara, R. (1993). Erzincan efsaneleri üzerine bir araştırma. Ankara: Erzincan Sosyal Yardımlaşma ve Dayanışma Vakfı Yayınları.

Kavruk, H. (2003). Türkçe mesnevilerde sebeb-i telif. Malatya: Özserhat Yayınları.

Khalidi, T. (2003). Müslüman Hazreti İsa. İstanbul: Kitap Yayınevi.

Kirdeci, A. (2002). Kesik baş destanı (M. Argunşah, Ed.). Ankara: Kültür Bakanlığı.

Köprülü, M. F. (2004). Türk edebiyatı tarihi (6. bs). Ankara: Akçağ Yayınları.

Kösoğlu, N. (Proje Yöneticisi.) (2001).Başlangıcından günümüze kadar Türkiye dışındaki Türk edebiyatları antolojisi nesir-nazım: Tatar Edebiyatı II (N. Yuziyev, Ed.). "Tatar Edebiyatı". c.18/2. (Latin harflerine ve Türkiye Türkçesi'ne aktaran Fatma Özkan). Ankara: Kültür Bakanlığı Yayınları. s. 93-99.

Kut, G. (2003). Supplementary catalogue of Turkish manuscripts in the Bodleian Library with reprint of the 1930 catalogue by H. Ethe. Oxford, UK: Oxford University Press.

Litvin, M. (2011). Hamlet's Arab journey: Shakespeare's Prince and Nassar's Ghost. Princeton, NJ: Princeton University Press. 
Menkabetnâme ve Risale-i Cemceme Sultan.[El Yazması] Arnavutluk Devlet Kütüphanesi. Nr. 443365. Arnavutluk Devlet Kütüphanesi Online Katalogu. Erişim adresi. http://www.bksh.al/Katalogu/ library/wwwopac/wwwroot/beginner/index_fr.html

Merhan, A. (2013). Dâsitân-ı Cümcüme: Anadolu'da Türk diliyle yazılmış ilk Cümcüme Sultan Destanı. VI.Uluslararası Türk dil kurultayı bildirileri kitabı içinde (s. 3133-3146). Ankara: Türk Dil Kurumu Yayınları.

Ocak, A. Y. (2013). Türk Folklorunda kesik baş: Tarih-folklor ilişkisinden bir kesit. İstanbul: Dergâh Yayınları.

Ørum, O. G. (2017). 'Ușșitil-Gumguma or 'the story of the skull' with parallel versions, translation and linguistic analysis of three 19th-century Judaeo-Arabic manuscripts from Egypt. supplemented with Arabic transliteration. Leiden-Boston: Brill.

Önler, Z. (1991). Manzum halk hikâyelerinden Cümcüme Sultan. Fırat Üniversitesi Dergisi (Sosyal Bilimleri), 5(2), 351-367.

Pennacchietti, F. A. (2005). Versioni cristiane e giudaiche di una legenda İslamica. Redefining Christian identity. In J. J. Van Ginkel (Ed.), Cultural interaction in the Middle East since the rise of Islam (pp. 291-299). Louvain: Peeters.

Redhouse, S. J. W. (2011). Turkish and English lexicon. İstanbul, Turkey: Çağrı Yayınları.

Rosni bin Samah. (2014/2). Malay takımadalarında tasavvuf edebiyatı (U. Boran, Çev.). Tasavvufilmî ve Akademik Araştırma Dergisi, 34, 109-128.

Padwick, C. E. (1930). The Nebi 'Issa and the skull'. The Muslim World, 20(1), 56-62.

Sakaoğlu, N. (2005). Türk Anadolu'da Mengücekoğulları. İstanbul: Yapı Kredi Yayınları.

Steingass, F. (1998). A Comprehensive Persian-English dictionary. Beirut: Librairie du Liban.

Şentürk, A. ve Kartal, A. (2006). Üniversiteler için Eski Türk Edebiyatı tarihi. İstanbul: Dergâh Yayınları.

Şişmanoğlu, N. (1991). Attâr, Feridüddin maddesi. Türkiye Diyanet Vakfı İlam Ansiklopedisi içinde (C. 4, s. 95-98). Ankara: Türkiye Diyanet Vakfı Yayınları.

Tansel, F. A. (1970). Cümcüme Sultân Ottoman translations of the fourteenth century Kıpchak Turkic story. Archivum Ottomanicum. C. 2, s. 252-269.

Tanyu, H. (1967). Ankara ve çevresinde adak ve adakyerleri. Ankara: Ankara Üniversitesi Illahiyat Fakültesi Yayınları.

Toker, M. ve Uygun, M. (2017). Çağatayca Cümcüme-nâme. Konya: Palet Yayınları.

Tottoli, R. (2003). The Story of jesus and the skull in Arabic literature: The emergence and growth of a religious tradition. Jerusalem Studies in Arabic and Islam, 28, 225-259.

Türker, Ç. (2011). Manzum halk hikâyeleri (Inceleme-metin-dizin). (Yayınlanmamış Yüksek Lisans Tezi). Çanakkale Onsekiz Mart Üniversitesi Sosyal Bilimler Enstitüsü, Çanakkale.

Yurttaş, H. ve Kındığılı, M. L. (2011). Kesinleşen tarih ve yeni bir ad. Atatürk Üniversitesi Edebiyat Fakültesi Sosyal Bilimler Dergisi, 11(46), 75-96. 